\title{
RESSONÂNCIAS DE SOBREPOSIÇÕES TEMPORAIS: ETNOGRAFIA NO BAIRRO KREUZBERG, BERLIM (ALEMANHA)
}

\author{
Cornelia Eckert ${ }^{1}$ \\ Ana Luiza Carvalho da Rocha ${ }^{2}$
}

\section{Obstáculo}

Como relatar uma experiência etnográfica realizada em equipe, de forma compartilhada: quatro olhos, quatro ouvidos, quatro mãos e quatro pés no tempo e espaço de um pós-doutoramento na Berlim de Walther Ruttmann, de Walter Benjamin, de Georg Simmel, de Alexander von Humboldt, de Berthold Brecht? Melhor prosseguir como sempre fizemos. Uma escreve, a outra entra no texto. Aliás, nestes vinte anos de coautoria, raros foram os momentos de escritura simultânea, o mais frequente é o ritual do debate antes, durante e depois: a primeira cria, a outra transforma, esperando que da metamorfose sempre saiam, não borboletas, mas interpretações das realidades sociais tais como elas se apresentam a nós, seguidamente ousando por uma diversidade estética narrativa (textos reflexivos, etnografias visuais, sonoras, banco de imagens) que possa as designar. Para iniciar a pesquisa, evocamos muitas vozes, a de escrituras como Walter Benjamin, Pierre Sansot, Gilberto Velho, William Foote Whyte, Michel de Certeau, Paul Ricoeur, Maurice Halbwachs, Gilbert Durand, Georg Simmel, Gastón Bachelard, George Perec, Marcel Proust, etc, a de imagens de filmes clássicos ou contemporâneos e, claro, a de intelectuais para nos desvendar as descontinuidades das estruturas políticas como nos ensina a obra de Hannah Arendt, estudos que nos orientam na percepção sensível dos deslocamentos na cidade de Berlim de setembro a novembro de 2013.

\section{Constrangimento}

Berlim, setembro 2013. O barulho de sirene é ensurdecedor. Vozes de soldados alemães com pisadas fortes e latidos de cachorros preenchem o ambiente. Meu coração dispara. Luzes acendem e simulam a perseguição visual de um(a) fictício(a) foragido(a).

\footnotetext{
${ }^{1}$ Universidade Federal do Rio Grande do Sul, Brasil.

${ }^{2}$ Universidade Federal do Rio Grande do Sul e Feevale, Brasil.
} 
As luzes ficam mais fortes, e atento para o muro de Berlim, com cerca de dois metros de altura, seus arames farpados e uma torre de controle.
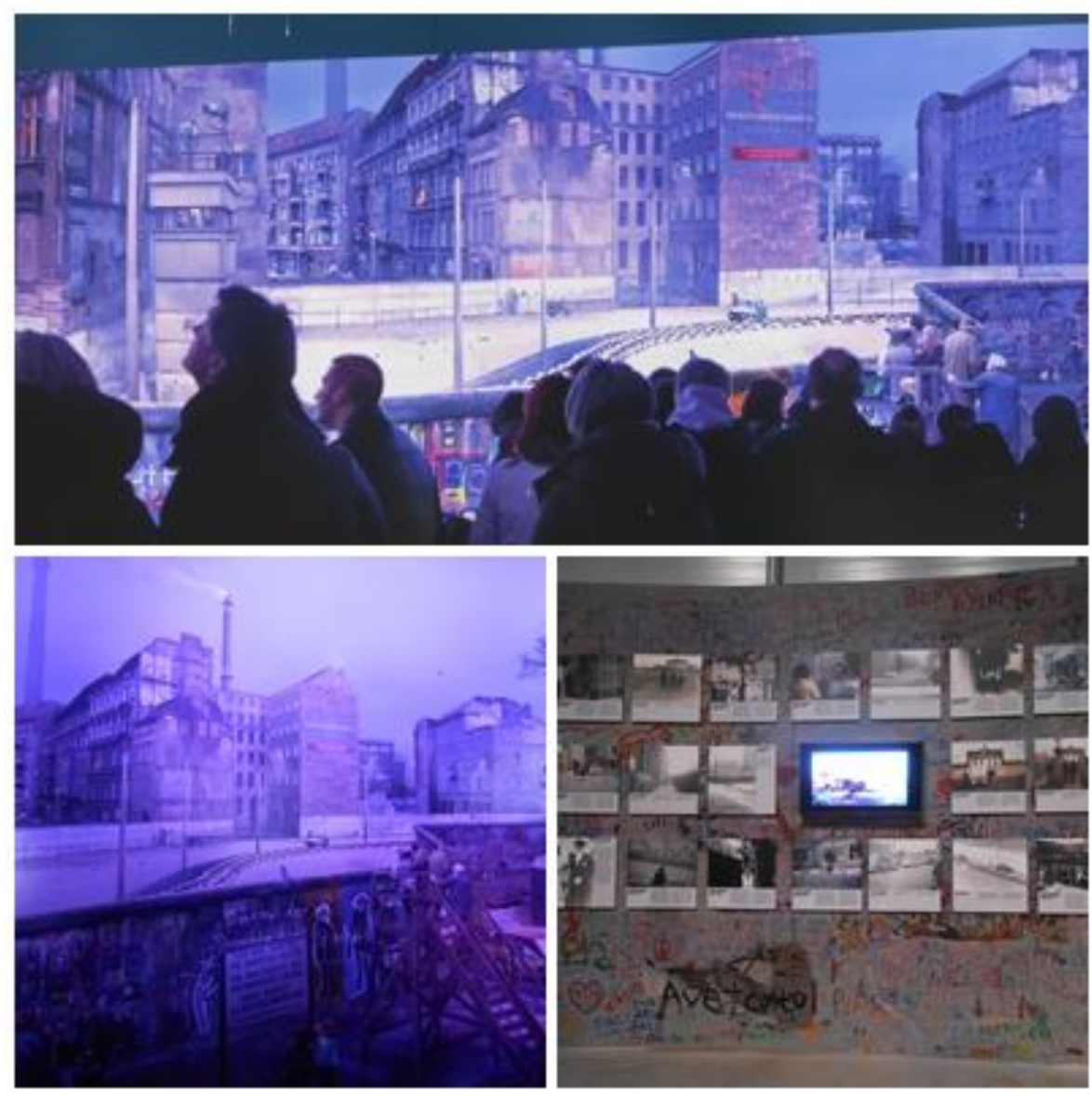

Das Mauer Panorama. Berlim, Alemanha, 4 de setembro 2013. Fotos de Cornelia Eckert.

Procuro por Ana Luiza. Ela já subiu o campanário para mirar o outro lado do muro. Sigo sua iniciativa e busco um ponto de observação panorâmico. Pensei em dizer para Ana que não estava me sentindo bem, mas não digo nada. Ana também parecia perturbada. Melhor aguentar. Quero dizer que me lembro da minha infância e me sinto fraca diante do trauma vivido pelos berlinenses naquele período, e que sinto saudades da minha mãe (falecida em 1998), que segurava minha mão ao olhar pela primeira vez aquela atrocidade de muro divisor: sentia medo. Lembro-me do meu pai (ainda vivo), que, como bom narrador, me contava a história desta cidade buscando em seu enredo trazer algum sentido histórico para existência do muro. Era 1962. Um ano antes, a 
cidade de Berlim oeste havia sido bloqueada, separada da Berlim leste, para permanecer nesta forma fragmentada até 1989.

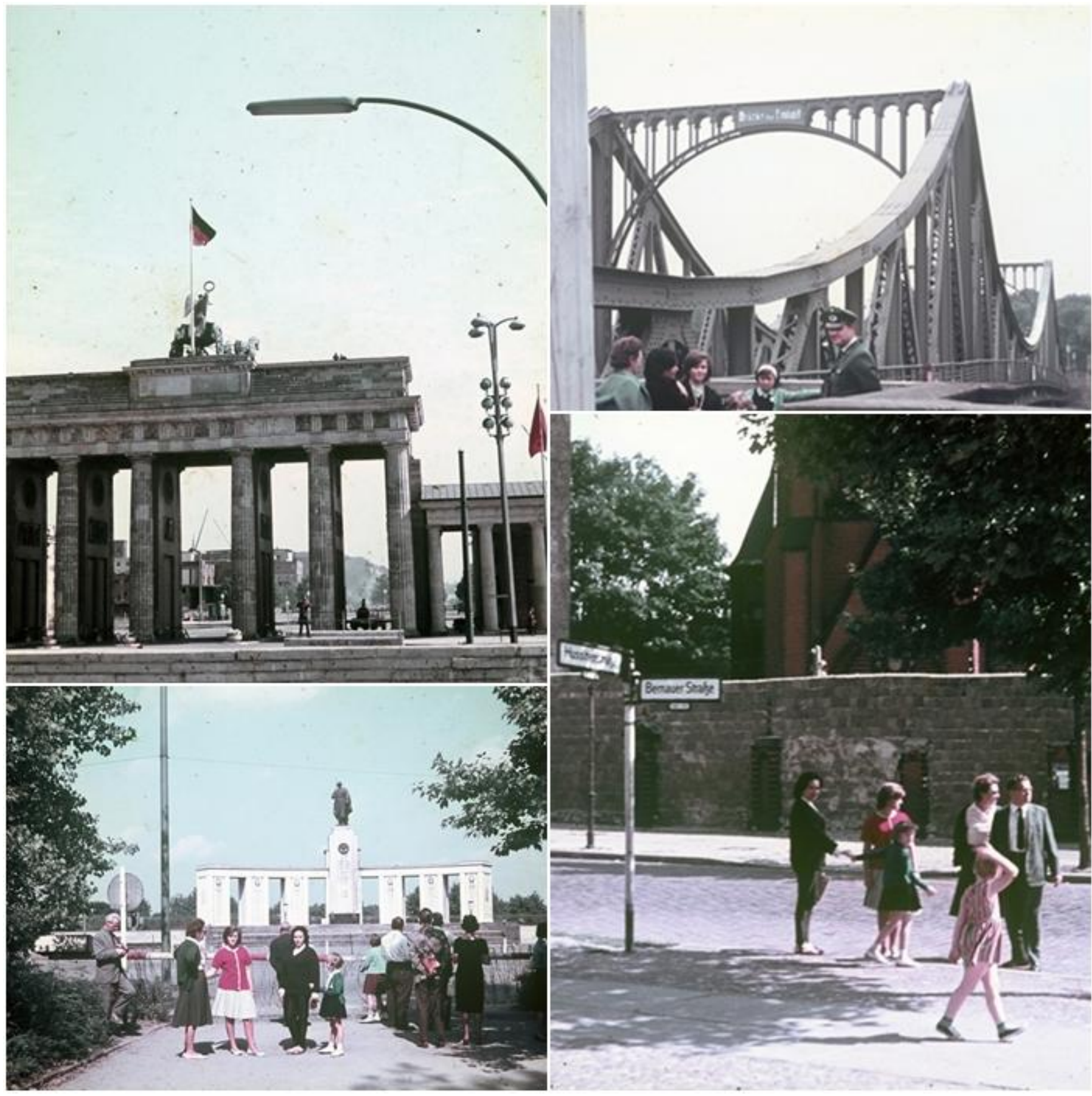

Berlim, 1962. Fotos de Kurt Benno Eckert 


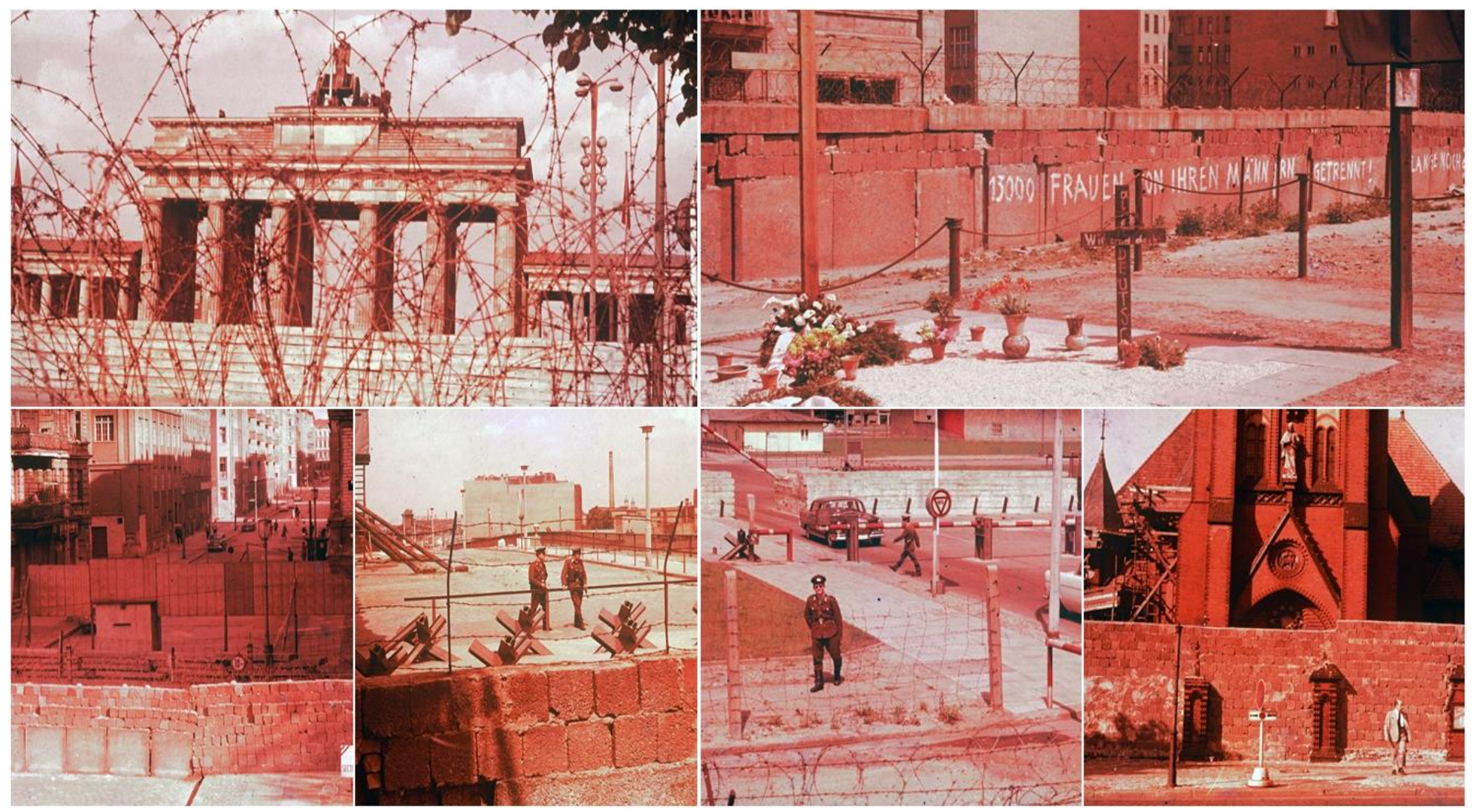

Berlim 1962. Slides comprados em quiosque de souvenir. Autor desconhecido.

Em 1971, também estivéramos eu e meus familiares na Alemanha, por ocasião de mais um estágio de aperfeiçoamento em teologia do meu pai. Nessa ocasião, fora possível conhecer o outro lado, junto com um grupo de famílias de luteranos em uma viagem solidária organizada pela igreja evangélica na DDR (Deutschland Democratic Republic). O outro lado? A uniformidade do tom cinza das moradias, filas para comprar alimentos, depoimentos de luteranos sobre seus esforços de resistência, a vida cotidiana e o medo da delação. 

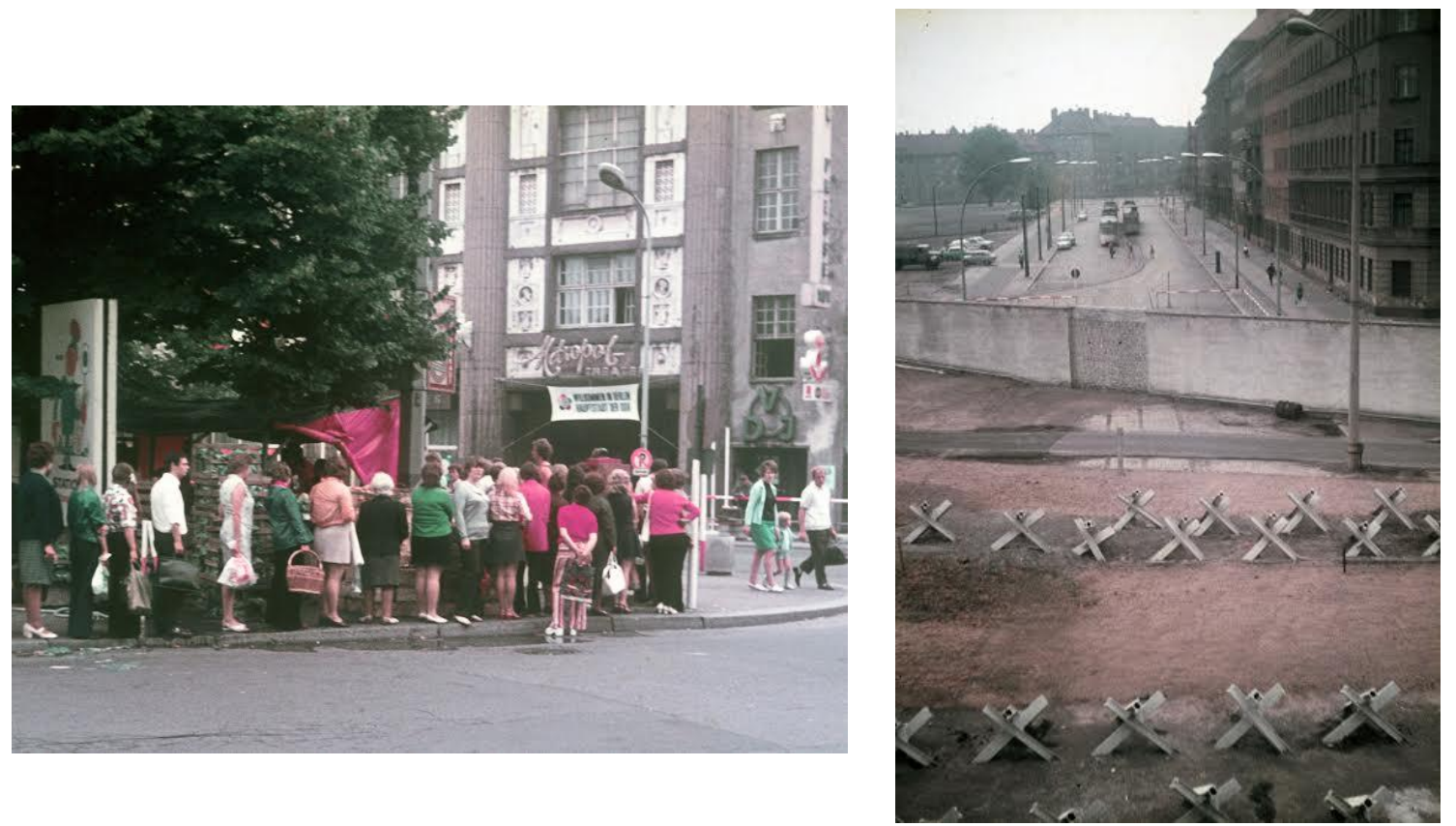

Berlim, 1971. Fotos de Kurt Benno Eckert

Finalmente quebramos o silêncio. Talvez a presença de algumas crianças barulhentas tenha nos tirado do torpor do momento. Juntas, tentamos refletir sobre detalhes da imagem projetada que simulava justamente nosso bairro, Kreuzberg. Que linha o muro desenharia na zona "barrial?" No lado ocidental, a imagem projeta uma ambiência efervescente de moradores caminhando despreocupadamente próximo ao muro, crianças jogando bola, ciganos, mercadores e, claro, as torres de observação. Após algumas suposições tentando imaginar a divisa entre a Kreuzberg da Alemanha Oriental e a Kreuzberg da Alemanha Ocidental, argumentamos sobre a funcionalidade de comprarmos um mapa que reproduzisse o traçado na época. Mudamos de ambiência no Museu do Muro. Em outra sala, percorremos alguns metros de muro original, onde imagens de época contavam histórias de fugas, de modo geral mal-sucedidas - por isso a imensa quantidade de cruzes e coroas de flores para ritualizar o luto. Conversamos com a vendedora da boutique solicitando material, que nos foi gratuitamente disponibilizado. Ana Luiza compra alguns postais e um livro histórico fomentando a coleção de imagens, meta de nossa rotina durante nossa estada de pós-doutorado em Berlim. Saímos do museu localizado no Checkpoint Charlie e seguimos em direção a outro território-monumento. 
É nosso terceiro dia na cidade de Berlim: 05 de setembro 2013. Os dias anteriores foram preenchidos com três ações básicas: instalação no apartamento alugado estrategicamente no bairro Kreuzberg; visita ao próprio bairro que seria nosso lócus de pesquisa participante diária e intensiva; e circulação de ônibus nas regiões centrais da cidade, tendo por ponto de partida e de chegada a Postsdamer Platz. No dia anterior, 04 de setembro, o passeio de reconhecimento do circuito dito turístico, visto do alto do segundo andar de um ônibus, permitiu a mentalização das complexas territorialidades da atual Berlim, agora nossa cidade. Da parada final, visualizamos, nas proximidades, as ruínas da igreja bombardeada na segunda guerra mundial, mais conhecida por igreja partida (Kaiser Wilhelm Gedachtniskirche, na Breitscheidplatz), ao lado da moderna torre hexagonal e do templo octogonal feita de vidros azuis. O cenário, mesmo tantas vezes filmado e fotografado (Der Himmel über Berlin -1987 de Wim Wenders), nos afetou, por mais habituadas que estivéssemos com o monumento.
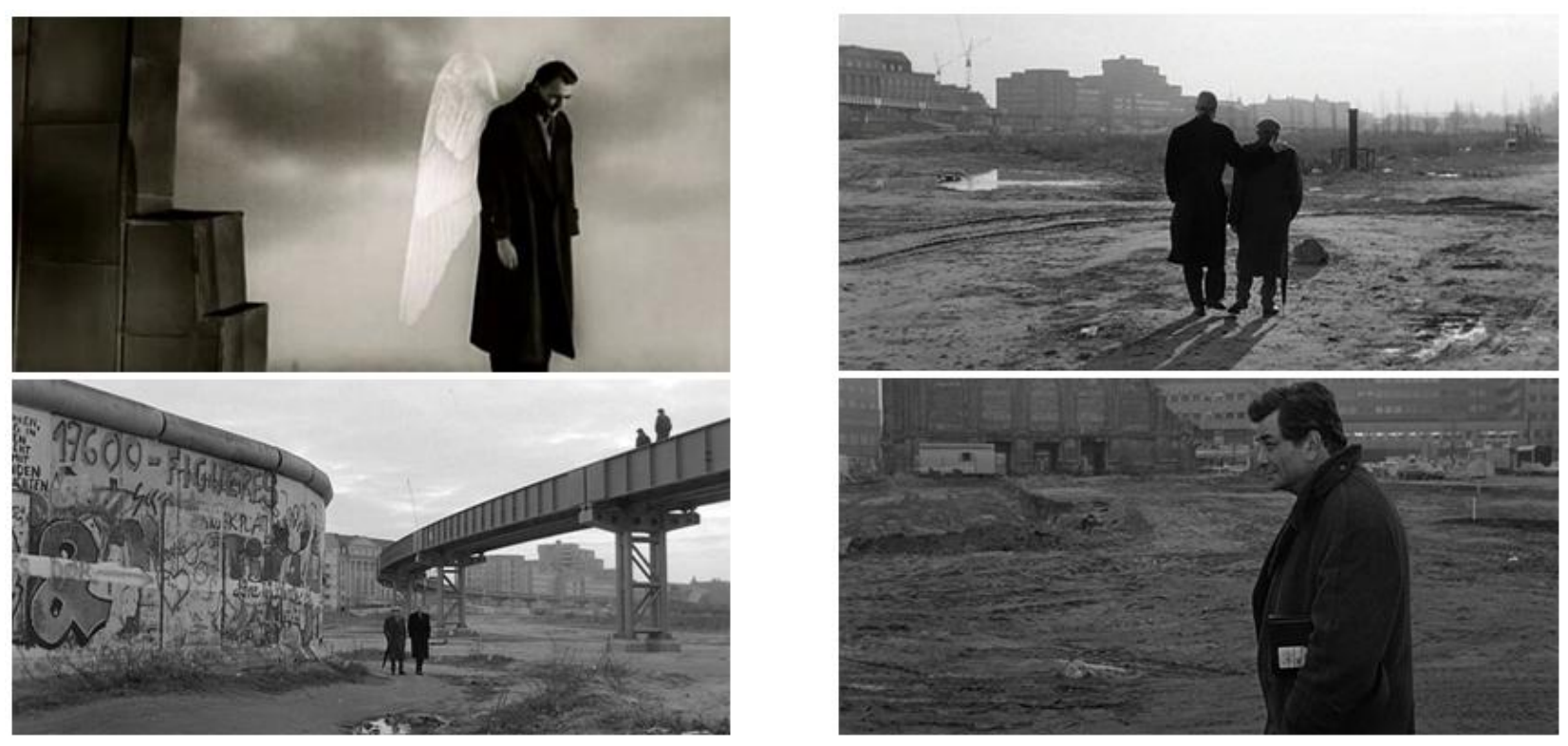

Cenas do filme Der Himmelüber Berlin - 1987 de Wim Wenders. Foto: Reprodução/Internet.

Tiramos fotos na medida em que nos aproximamos do memorial. Eu, como sempre, na busca do meu tempo perdido (aus das Kind kind wa - voz em off no filme de Wim Wenders), estava comovida pelas reminiscências da infância e da adolescência. Lembrava do encantamento do meu pai e da minha mãe em 1962, das novas instalações da igreja evangélica luterana com seus vitrais fantásticos um ano após sua inauguração, 
ocasião em que escutamos um concerto de órgão de Bach. Para mim, uma parada obrigatória. Ana lembrava que, no ano anterior, em 2012, eu também insistira da mesma forma: "vamos entrar e escutar o órgão!" Sim, em 2012, tínhamos passado em julho rapidamente pela cidade para contatar Ingrid Kummel, que viria a ser nossa orientadora de pós-doutorado em 2013. A ruína nos lembrava das inúmeras imagens que tínhamos que acervar da Berlim destruída na II Guerra e os inúmeros museus a vencer sobre o tema.

Caminhamos pela Zimmerstr/Niederkirchner Str. Para alcançar o local definido por Topografia dos Terrores. Nossos humores já estavam abalados, mas estávamos ansiosas por conhecer a linha de tempo da Berlim sob jugo nazista (1933 a 1945) proposta por este museu a céu aberto ao lado de muros ainda reminiscentes (1961 1989). Tantas pluralidades de tempos de guerras, partidos políticos e conflitos davam um nó em minha cabeça. Ana e eu nos separamos para cada uma fazer o percurso no seu ritmo. O longo trajeto linear a ser percorrido propunha uma sequência cronológica dos acontecimentos do período nazista, tendo, por expografia, pôster gigantesco com múltiplas imagens, textos, propagandas nazistas que endeusavam Hitler e demais autoridades que perseguiram judeus e outras minorias.
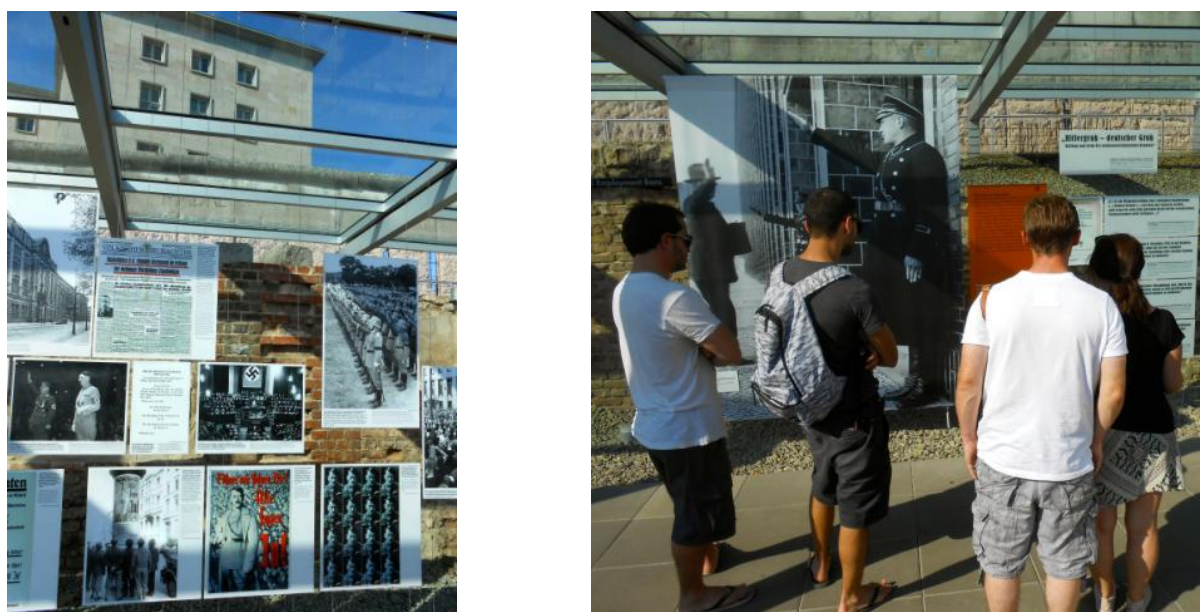

Berlim, setembro 2013. Centro de Documentação Topografia dos Terrores. Fotos de Cornelia Eckert 


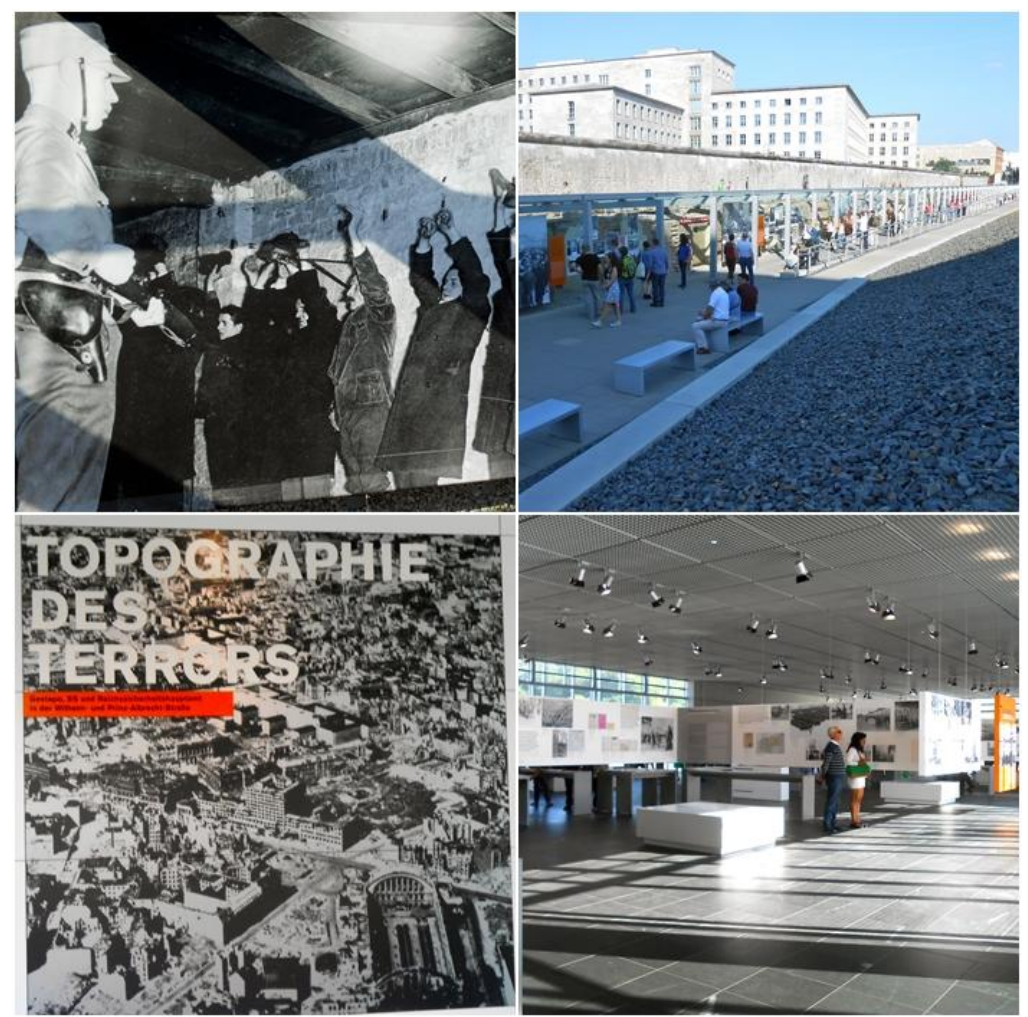

Berlim, setembro 2013. Centro de Documentação Topografia dos Terrores. Fotos de Cornelia Eckert
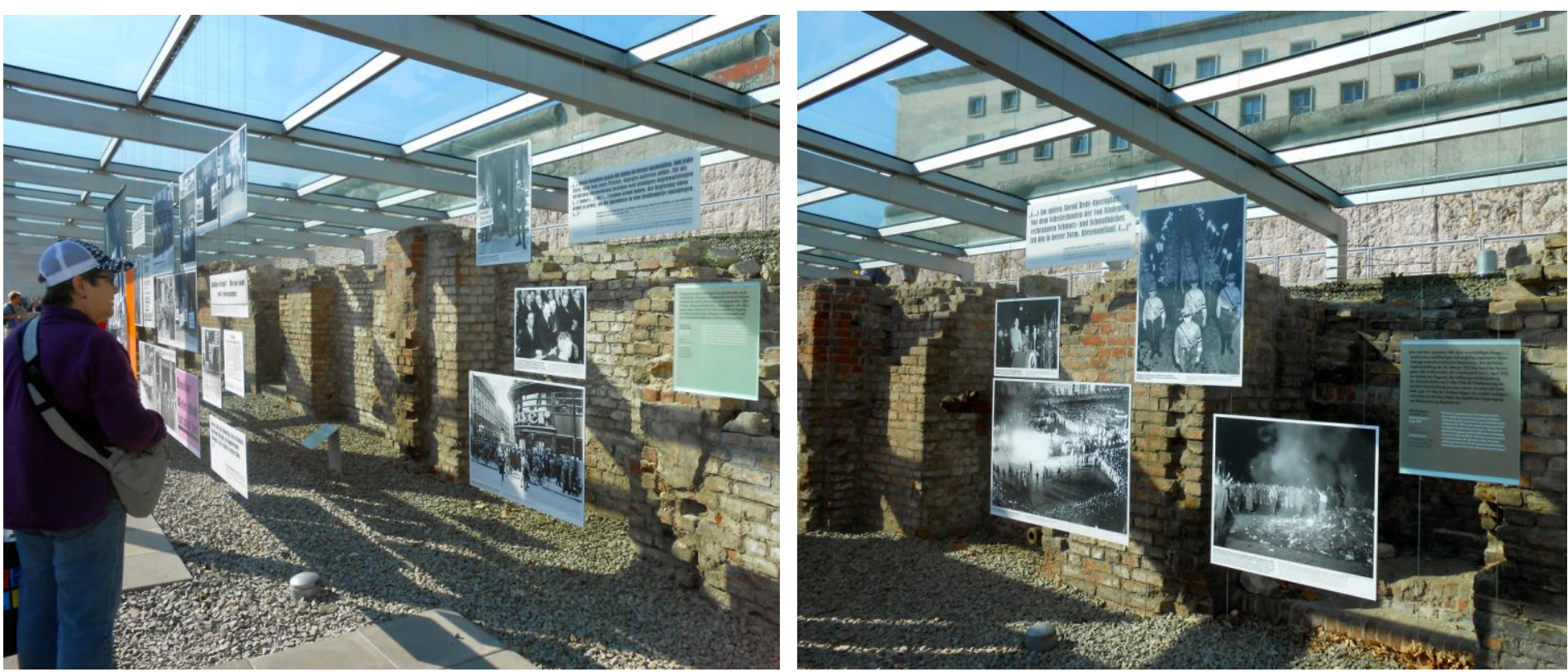

Na sequência, me dirigi ao Centro de Documentação, que, já na entrada, anuncia ter sido construído sobre os escombros da sede da Gestapo (SS) e de inúmeras salas de tortura. Documentei a nossa visita com algumas fotos dos horrores, e minha mente 
viajava lembrando de tantos filmes hollywoodianos e documentários que retratam o período.

Tendo escrito em 2009 o texto "Etnografia da duração: estudos de memória coletiva", sentíamos no interior da imagem vertiginosa do Print Gallery de Maurits Cornelis Escher.

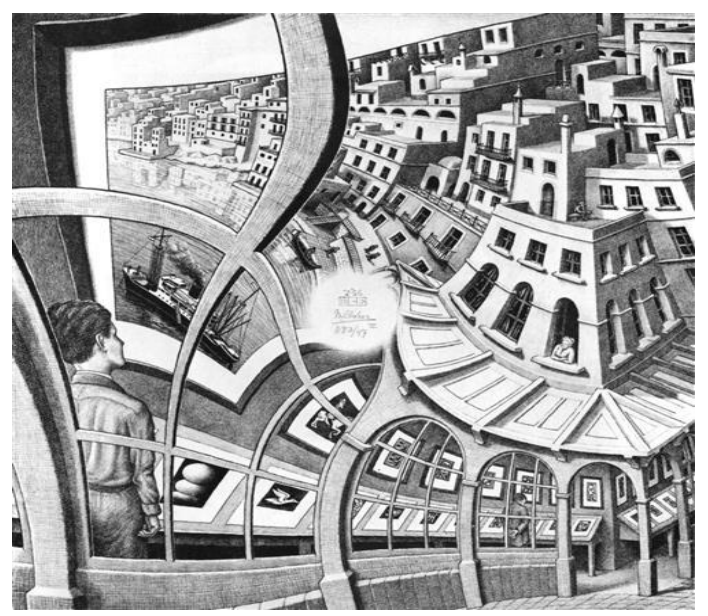

Fonte: http://www.wikiart.org/en/m-c-escher/print-gallery. Consulta 15 outubro 2013

Esta imagem tinha sido por nós selecionada para dialogar com a obra de Gastón Bachelard; ela definia o nosso projeto de pesquisa, tratar das múltiplas imagens na cidade para propor, na forma de arranjos constelares em relações semânticas, uma interação com as experiências temporais dos habitantes nas cidades. Mas o desafio de tratar deste nível de complexidade das camadas temporais de uma cidade, não estaria muito além de nossa capacidade de articular uma pesquisa interpretativa? Não teríamos nós pecado na prepotência de uma etnografia acelerada mesmo que dominando há vinte anos a estratégia da flannerie com produção imagética nas ruas e bairros citadinos? Porto Alegre, Paris, Buenos Aires, Belém, Rio Tinto, Manaus, Florianópolis, Cachoeira do Sul, Guaíba, Viamão, Maceió - muitas foram as cidades onde ensinamos a etnografia nas ruas locais com instrumentos audiovisuais, isto sem falar dos vinte anos do projeto Banco de Imagens e Efeitos Visuais e a capacitação acadêmica para pesquisar com imagens que evocam as sobreposições temporais que ritmam a duração dos habitantes em uma cidade em suas memórias.

Decisão de seguir apenas o que nossos corpos suportariam na rotina acadêmica, burocrática e etnográfica, três tons que guiariam nosso court séjour na complexa 
Berlim. O desafio era repertoriar densamente e criticamente a passagem do tempo, ou, como gostamos de sintetizar, tomando Berlim e mais precisamente o bairro Kreuzberg como objeto temporal em múltiplos movimentos, episódios, acontecimentos e, sobretudo, a ambiência “barrial”, neologismo do antropólogo argentino Ariel Gravano só para não esquecer que a unidade espacial "barrial", bairro, micromundo, microuniverso, espaço praticado, comunidade urbana, lembra da nossa pertença à linhagem da antropologia urbana, desde os tempos de Max Weber no ensaio "A Cidade" (1921) ou de Jane Jacobs (1961) perguntando sobre os usos do bairro na crítica aos planejadores urbanos. Para responder ao modismo conceitual desta era antropológica, seria o caso de tomar o bairro como um não-humano e refletir sobre suas agências? Bem, tudo importa, mas em especial a pergunta de Georg Simmel referindo-se aos metropolitanos, como pulsa a vida?
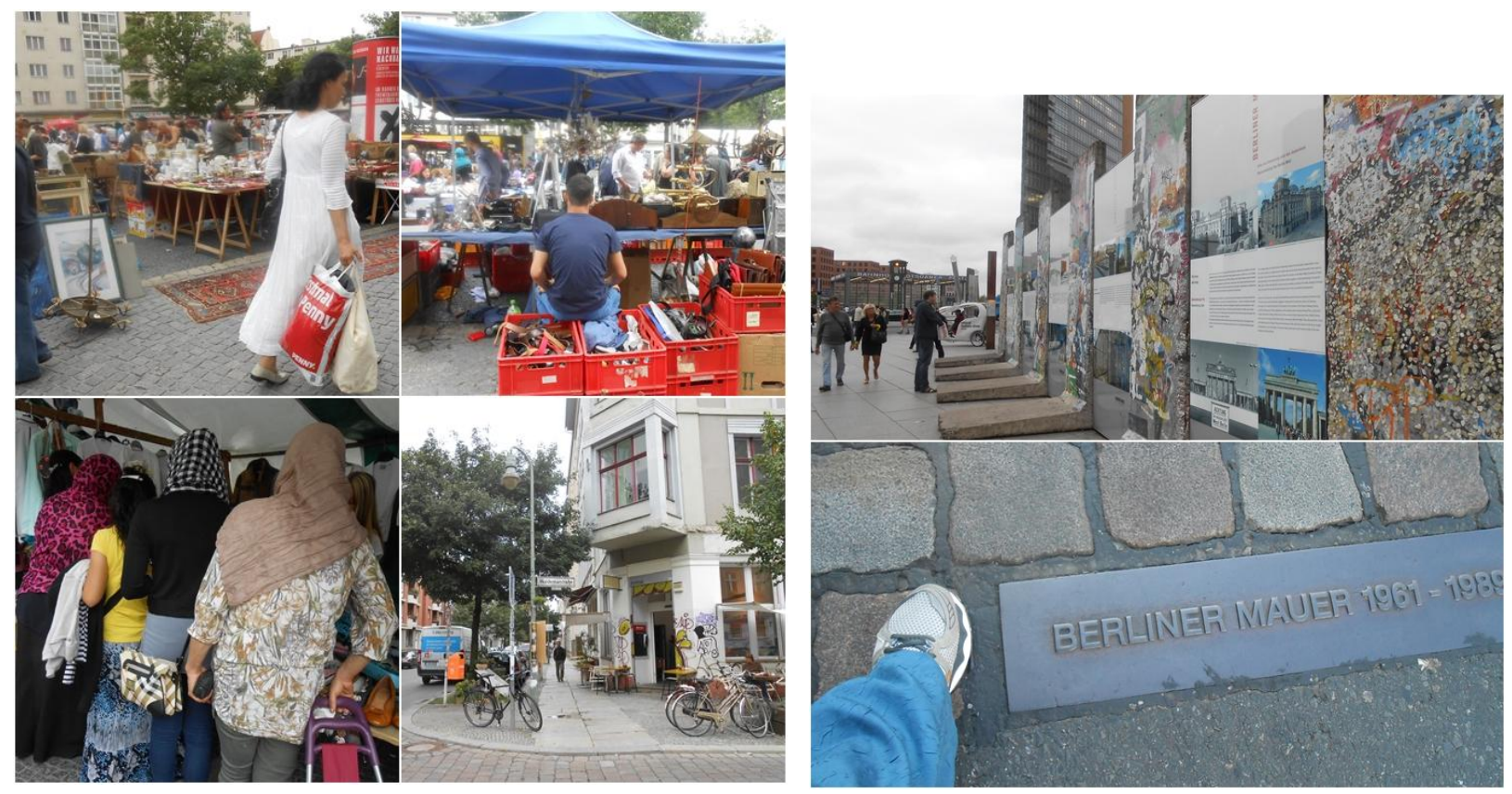

Berlim, setembro 2013. Fotos de Cornelia Eckert

Resolvemos trabalhar com um ponto de inflexão, a queda do muro "da vergonha" (Berlim, 1989) e o que, no nível micro social, podíamos conhecer das transformações 
no bairro junto a moradores. O quê, no nível mesoético ${ }^{3}$ ou institucional, poderíamos reconhecer como ações políticas, sociais e culturais criativas de mediadores e atores nas gestões de diferentes níveis (em destaque a política da multiculturalidade e integração)? O quê, no nível macro estrutural do "triunfo do liberalismo, do capitalismo, das democracias ocidentais sobre as vãs esperanças do marxismo" (Latour, 1994: 13), poderíamos compreender em torno dos discursos sobre um Ocidente liberal que triunfa e engendra um estado global e intensifica as assimetrias econômicas. Estranha dialética esta que reforça o pessimismo definido por Georg Simmel como o da tragédia da cultura para o mundo moderno em sua sequência de conflitos, invenções, guerras e prepotências e estados corruptos. Os taxistas em Berlim nos contaram vários escândalos: vocês sabem quando vão inaugurar o novo aeroporto Brandenbourg? "Nunca", sentencia o taxista, e continua "Aquele terreno não presta, nenhum avião pode aterrissar lá. Já se foram bilhões, ladrões, má gestão. E sabe quem esta ganhando? As multinacionais" (Episódio ocorrido em 08 de setembro 2013).

Por onde andássemos, no domingo, dia 08 de setembro 2013, havia alguma manifestação pública. Recorremos ao diário de Cornelia Eckert

Diário de Campo, segunda-feira, 9 de setembro 2013

Domingo, 8 de setembro 2013. Caminhada no centro. Errando pela Karl Liedknecht Strasse, saindo da Berliner Dom até a Alexander Platz, sentíamos uma tensão no ar. $\mathrm{O}$ mal estar era pela grande quantidade de policiais na rua. Todos em prontidão como próximo de algo que poderia estourar. Estranhamos. Seria pelo impressionante número de turistas circulando? Em uma massa histérica sempre pode haver mortes. Aos poucos um barulho de manifestação, apitos e gritos de ordem nos chama a atenção. Era um protesto com muita gente. Muito colorido, cartazes, balões, muitas famílias e crianças. Hoje cedo comprei um jornal para entender o que foi esta manifestação. Agora que escrevo este relato já li o noticiário e entendo que a demonstração era contra muitas coisas: os baixos salários; excesso de monitoramento; comercialização; aumento dos aluguéis; PD e racismo; ruído dos aviões e BER; Matança de cães vadios; política de péssimo atendimento público. Participaram 20 mil ativistas segundo a reportagem do jornal Berlin \& Umland p. 11, de 8 setembro 2013.

Voltando a nossa longa caminhada do dia anterior, terminamos nosso destino claro na Brandenburger Tor. Dada a distância foi uma caminhada com muitas paradas para descansar e tomar água. $\mathrm{Na}$ frente da embaixada americana havia uma manifestação. Inicialmente considerei ser uma manifestação contra um possível ataque americano na Síria, mas os discursos em árabe, a bandeira que não identifiquei como sendo da Síria ou da vizinha Líbano, as fotos dos líderes, não

3 Conceito proposto por Roberto Cardoso de Oliveira em Antropologia e Moralidade. http://www.anpocs.org.br/portal/publicacoes/rbcs_00_24/rbcs24_07.htm, consulta 02 junho 2014. 
permitiam saber do que se tratava. Talvez Iranianos. Bem, todos os dias há protestos em frente a embaixada americana e certamente muitos povos ali se sucedem.

Aproveitei para fotografar o imenso espaço em reformas para a criação da estação de metro U 55 que transtorna a vida dos usuários, tudo fechado desde a torre de televisão até o arco. Do arco fomos em direção ao cemitério judeu e um buzinasso e um foguetório escandaloso nos chamou a atenção. Nossa! Mais uma manif (parece Paris, França). Seria agora os judeus? Desta vez era um cortejo que seguia o carro dos noivos que se casaram. O carro era escandalosamente enfeitado com flores. Os machos gritavam, cantavam, seguravam bandeiras de seus países de origem, turcos? alemães? Não dava para saber, melhor jogar na coluna do meio. E um ônibus privado com os convidados fechava o cortejo.

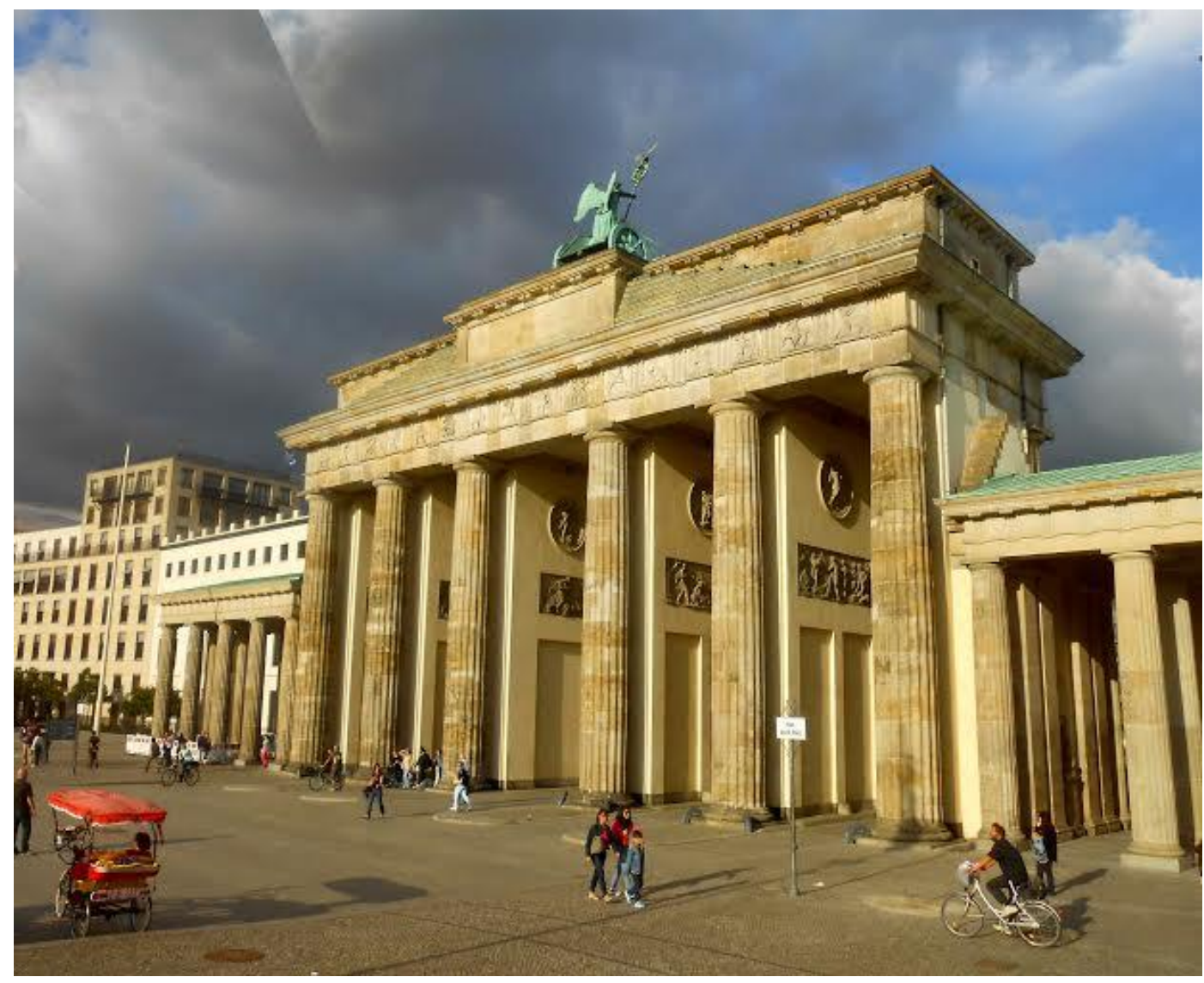

Berlim, 9 de setembro 2013. Torre Brandenburger. Fotos de Cornelia Eckert. 

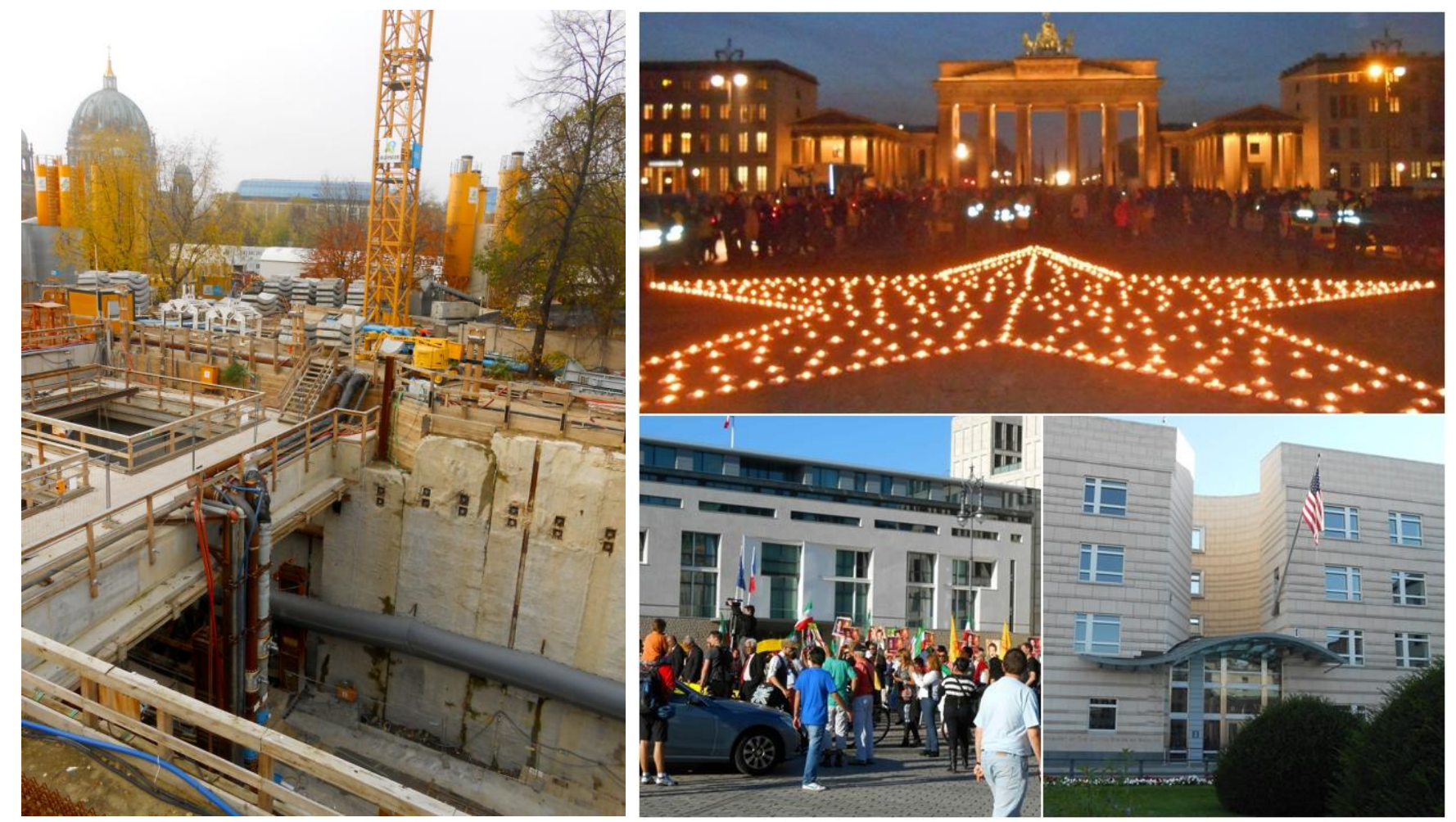

Berlim, 9 de setembro 2013. Torre Brandenburger, Embaixada Americana. Fotos de Cornelia Eckert.

\section{Deslocamento}

Deslocamentos impressionistas, alteridades próximas, alteridades mais do que próximas, sempre deslocamentos. A cidade, o bairro se impõe a nós, sugere a leitura do livro de Pierre Sansot intitulado La poétique de la ville. Pegamos o metrô na estação Gorlitzer, linha 1, o primeiro trecho de todos na história do equipamento moderno. $\mathrm{O}$ metrô anda um bom trecho na superfície e revela uma cidade que é um grande canteiro de obras. Caminhar no centro, na ilha dos museus, por exemplo, nos deixa estupefatas Enormes guindastes reconstroem o castelo Humboldt, ao lado da Universidade Humboldt, da biblioteca Humboldt. A "Humboldtlândia" estava sendo "gentrificada". Um ano antes havíamos visto o minucioso trabalho de arqueólogos. Agora os tapumes não permitiam mais enxergar e somente os barulhos das máquinas predominavam no imenso território da futura construção que prevê simular um castelo. 


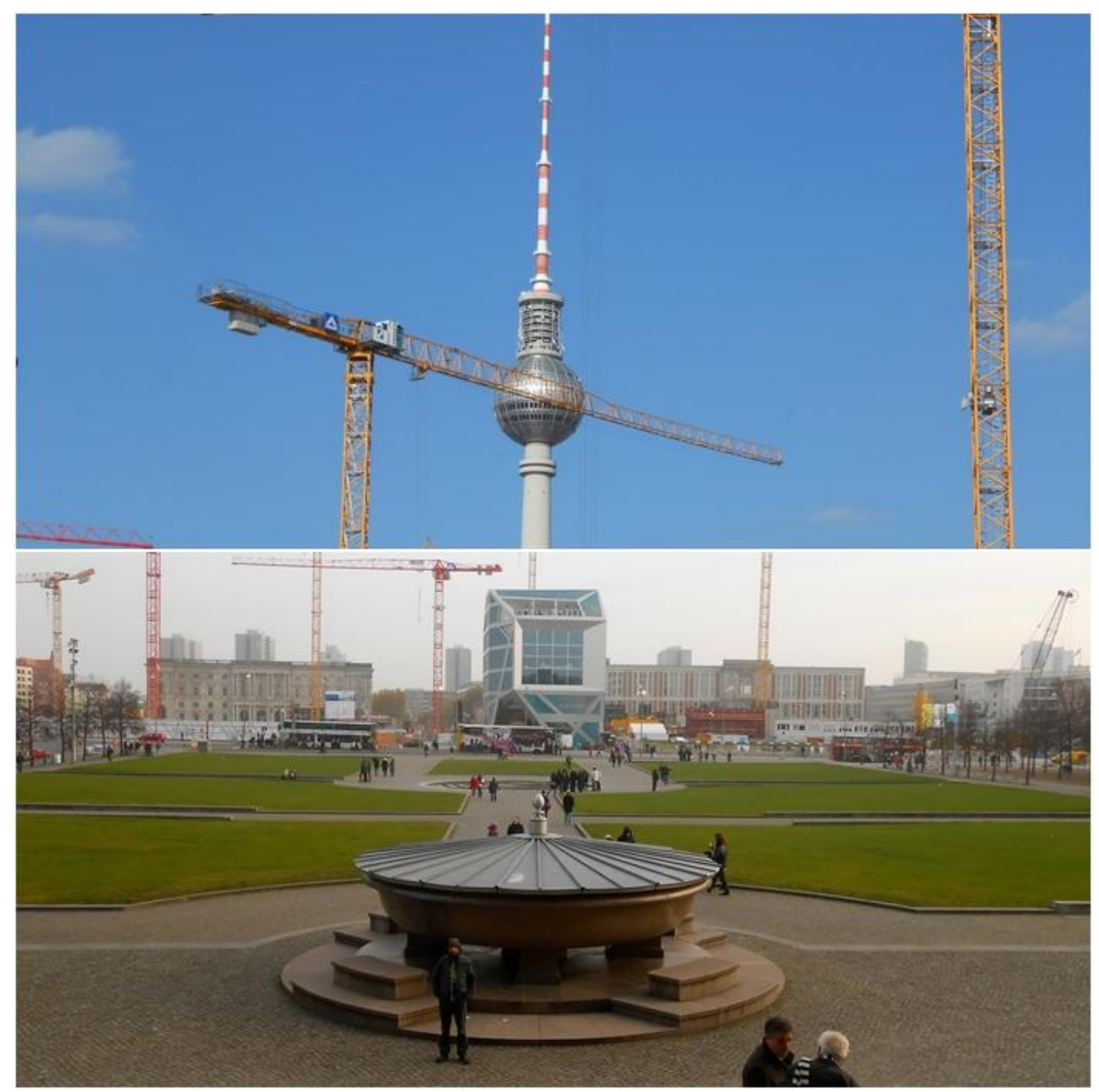

Berlim, setembro 2013. Reformas na ilha dos museus. Fotos de Cornelia Eckert 


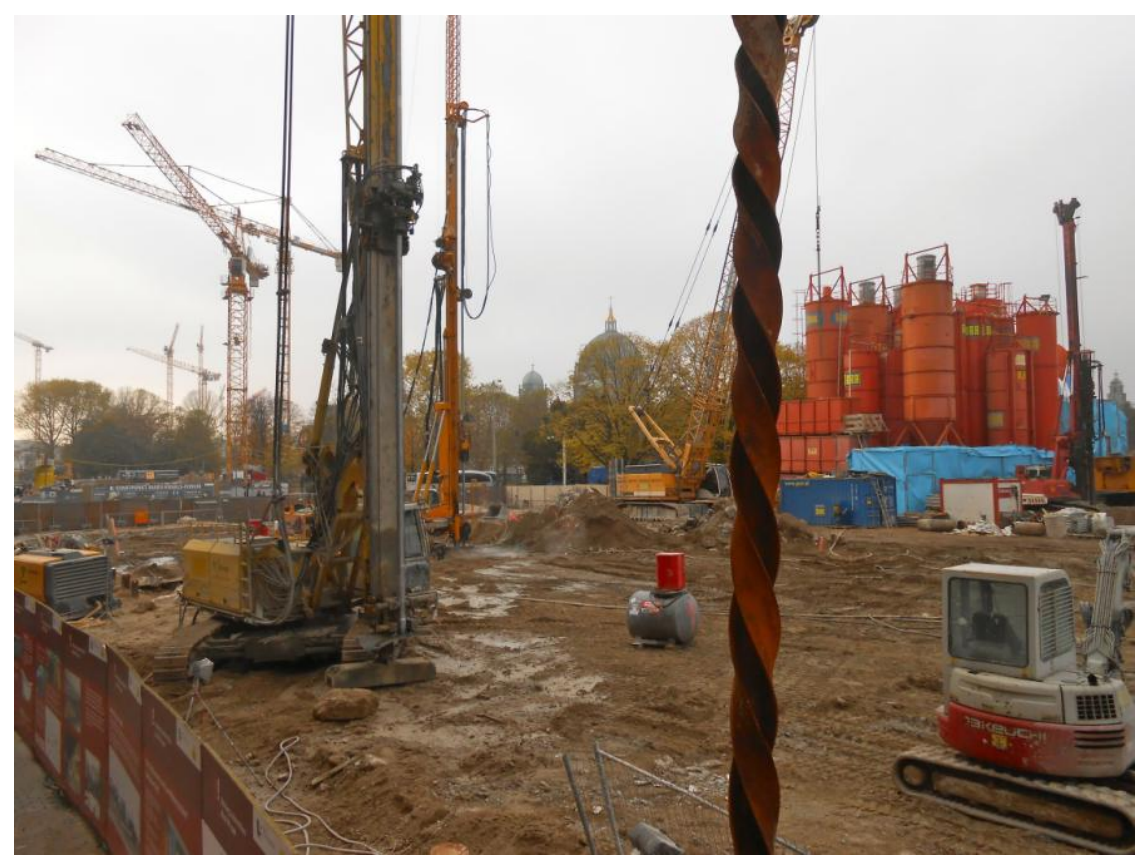

Berlim, setembro 2013. Reformas na ilha dos museus. Fotos de Cornelia Eckert

A unificação devolveu a Berlim o status de capital da Alemanha. A cidade estava em pedaços e sua reconstrução seguia dois lemas que nossos interlocutores em geral repetirão como um mantra. Primeiro, "vocês não conhecem o refrão que o prefeito de Berlim, Klaus Wowereit, pronunciou para acelerar um cosmopolitismo? "Pobre, mas sexy”, ele diz desde 2004. Wowereit é prefeito desde 2001. Foi eleito pelo Partido Social-Democrata da Alemanha (SPD). Esta referência ao leimotiv da gestão do atual prefeito para as reformas urbanas em Berlim, foi citada na primeira entrevista que realizamos com a antropóloga alemã Maria Lindola, professora na Universidade Livre de Berlim. O segundo lema é singularizado no conceito de multiculturalismo. Este conceito rege a maioria das políticas de governo da nova Berlim: de educação, de cultura, de saúde pública. As linhas de pesquisa, no catálogo do Instituto LatinoAmericano que abriga nosso pós-doutorado, bem comprovam a predominância desta categoria interpretativa em suas preocupações.

O velho caminha acompanhada do anjo na Postdamer Platz destruída pelas bombas na guerra implacável. Senta-se em uma poltrona e pergunta onde ficou aquele lugar vivo, onde estão as pessoas, as crianças, o que aconteceu? Win Wenders roteiriza o que podemos facilmente imaginar ao lá chegar: os ritmos das destruições criativas e das construções destrutivas. Conceitos estes de Nietzche citado por David Harvey em seu estudo sobre a condição pós-moderna (1993). Fotografamos as ruínas. 
Outro deslocamento, o bairro, nosso bairro, Kreuzberg. Escrevo em meu skype, "sou kreuzberger", Ana escreve, "em Berlim com os berlinenses". Nossos movimentos de nos desfamiliarizarmos e de familiarizarmos no contexto, eram paradoxais. Mais confortos que desconfortos aos significados afetivos do bairro. Enraizamento rápido no ritmo cotidiano entre o reconhecimento simbólico e a curiosidade etnográfica. A escrita do relato, sempre a noite, no quarto alugado, é rodeado de mapas, fotos e de livros. O relato denso, instrumento sensato da prática etnográfica e tantas outras estratégias ensinadas desde os tempos da escola de Chicago: estudo de redes sociais, relatos biográficos, construção de trajetórias sociais, etc. Só que naquela época não havia a internet, que avanço. Encontro muitos relatos de turistas sobre o bairro, muitos de brasileiros. Muitos filmes, curtas, de estudantes turcos sobre o seu bairro, projetos de escola, oficinas culturais.
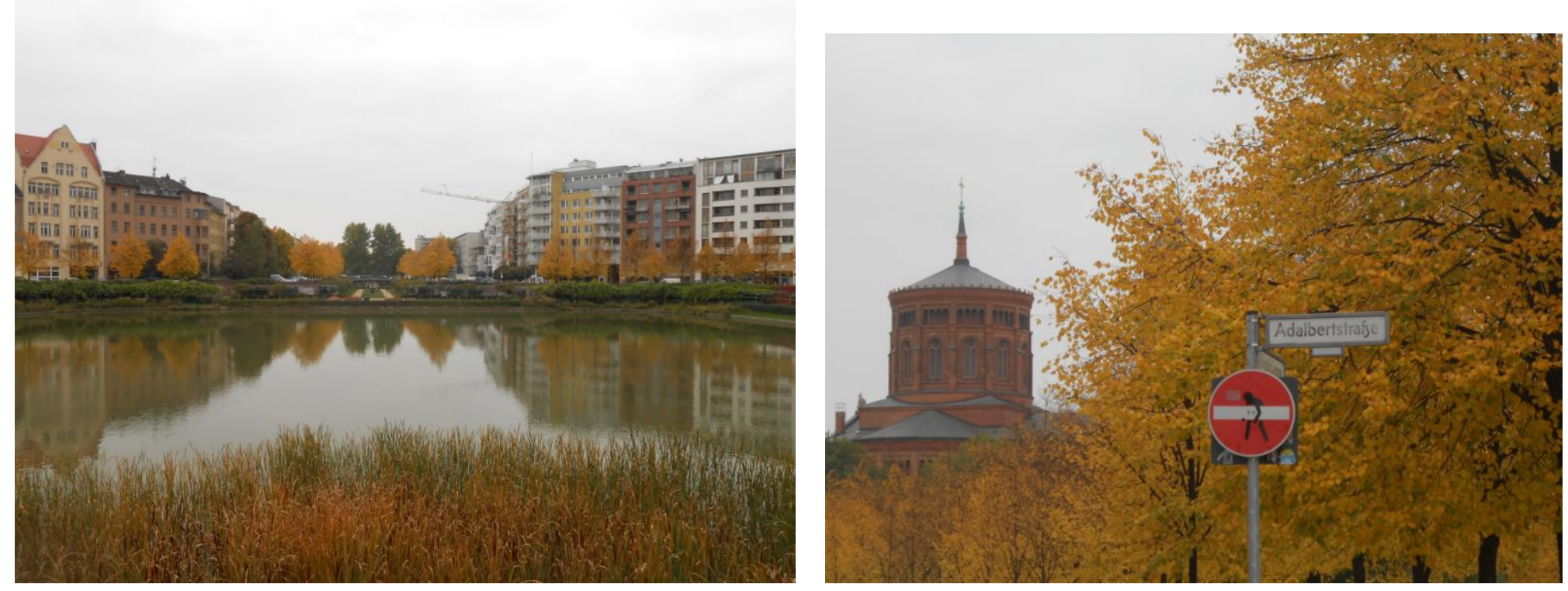

Berlim, outubro 2013. Bairro Kreuzberg. Fotos de Cornelia Eckert 

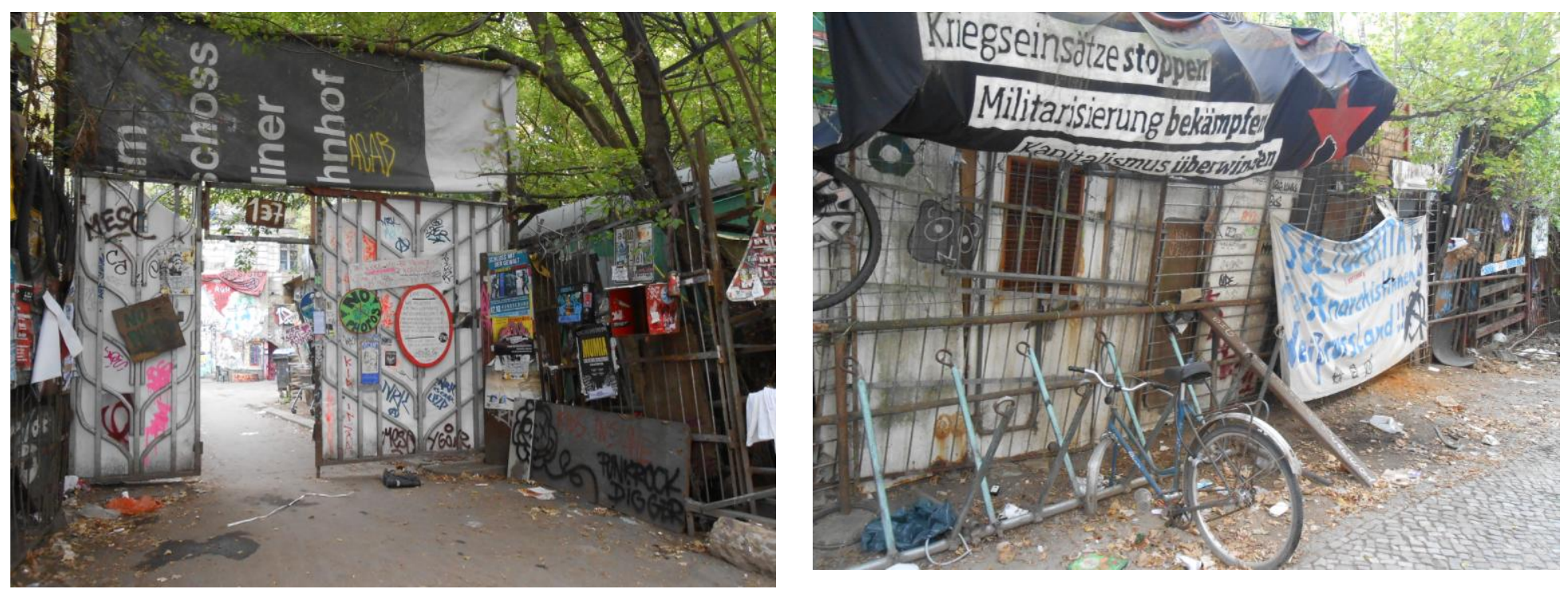

Berlim, outubro 2013. Bairro Kreuzberg. Fotos de Cornelia Eckert

Que lugar era este, o nosso bairro? Que palavras ouvíamos? Quem eram seus habitantes? Por que tanto fascínio publicitário pelo bairro para o navegador turista. Em Berlim, Kreuzberg desponta como o bairro da moda (Roldão, 2013). Mas como interpretar a presença de lixos acumulados por algum tempo. A polêmica estava no ar. Leio um panfleto que reclama da imundície do bairro e denuncia a prefeitura e outras instituições de nada fazerem para intervir no que se considera um retrocesso na limpeza pública. Lembrei-me do movimento "pas de caca" que cheguei a etnografar em nosso bairro Belleville, durante outro pós-doutoramente em 2001, em Paris. 

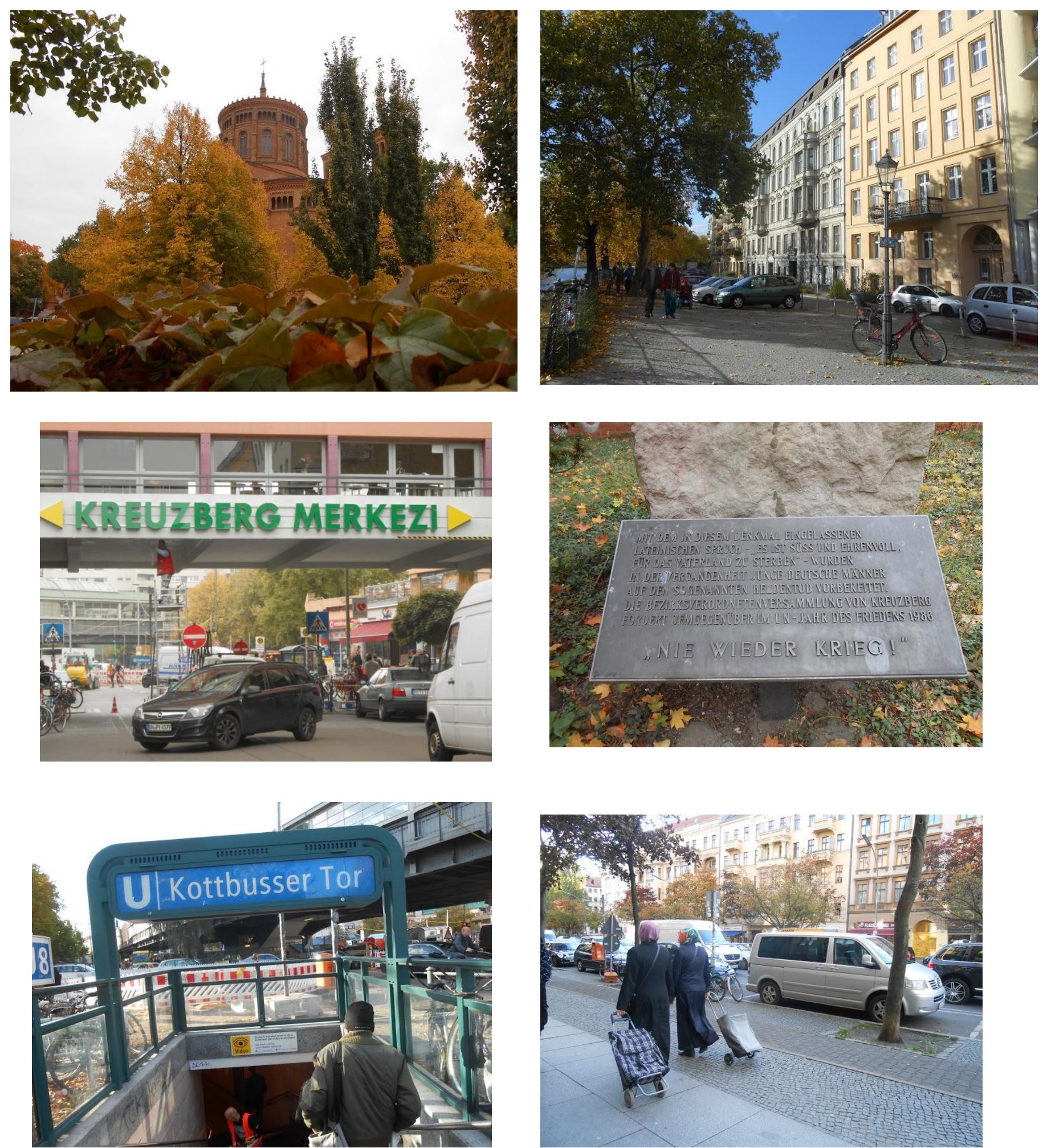

Berlim, outubro 2013. Bairro Kreuzberg. Fotos de Cornelia Eckert 
A estação de metrô era imunda, as paredes dos edifícios pichados, e alguns sinais de miséria, a displicência eram constantes e alguns cantos com odor de urina eram fortes. Fotografei o chão para mostrar a quantidade de pontas de cigarros e outros restos psicoativos que eram consumidos sem medo. Sim, o fato social total de Mauss, não a trimedimensionalidade apenas, mas a experiência simmeliana holística da visualidade, do auditivo e do olfativo. O sujo não era sinônimo de outras dilacerações do cotidiano brasileiro. Nada de atrasos dos metrôs, nada de metrô cheio, ônibus a vontade, horários previamente definidos.

O trajeto na Manteuffelstrasse do metrô até nossa casa era um cenário que rapidamente me encantava, sobretudo a primeira parte, na esquina o restaurante mexicano sempre colorido e do outro lado da rua, uma imensa parede grafitada. A sequência de quadras, o pulsar urbano, casas do séc. 18, 19, 20? Melhor, prédios no estilo hausmaniano, 8 a 9 andares (sem elevador em geral) seguia um belo colorido. Em torno das árvores diversas, mini jardins rodeado de bancos. Aliás nas ruas, quiosques, bares, restaurantes turcos, e sempre uma mesa e bancos convidativos para uma breve parada. Alguns oferecendo cobertores para aguentar as baixas temperaturas. Não tinha como não bater ponto na esquina do sugismundo, pelo menos eu o estigmatizei assim, mas apenas por ele me lembrar um personagem também estigmatizado na publicidade brasileira famoso nos anos 70 em prol de uma política pública de cuidados de higiene no Brasil.

O sugismundo de Kreuzberg mais parece um hippie também dos anos 60 e 70. Ele administra uma boutique ou espelunca de roupas usadas, um lugar muito sujo que não tivemos coragem de adentrar. Na rua, ele mantém uma camionete onde roupas são ofertadas por preços diversos. Mas quando perguntamos o preço de um casaco de inverno pendurado em cabide na calçada, este nos pareceu exorbitante para o estado da roupa usada. Sugismundo era um cadeirante que passaríamos a encontrar não só na esquina de casa, mas também nos trajetos que fazíamos como nosso ônibus. 

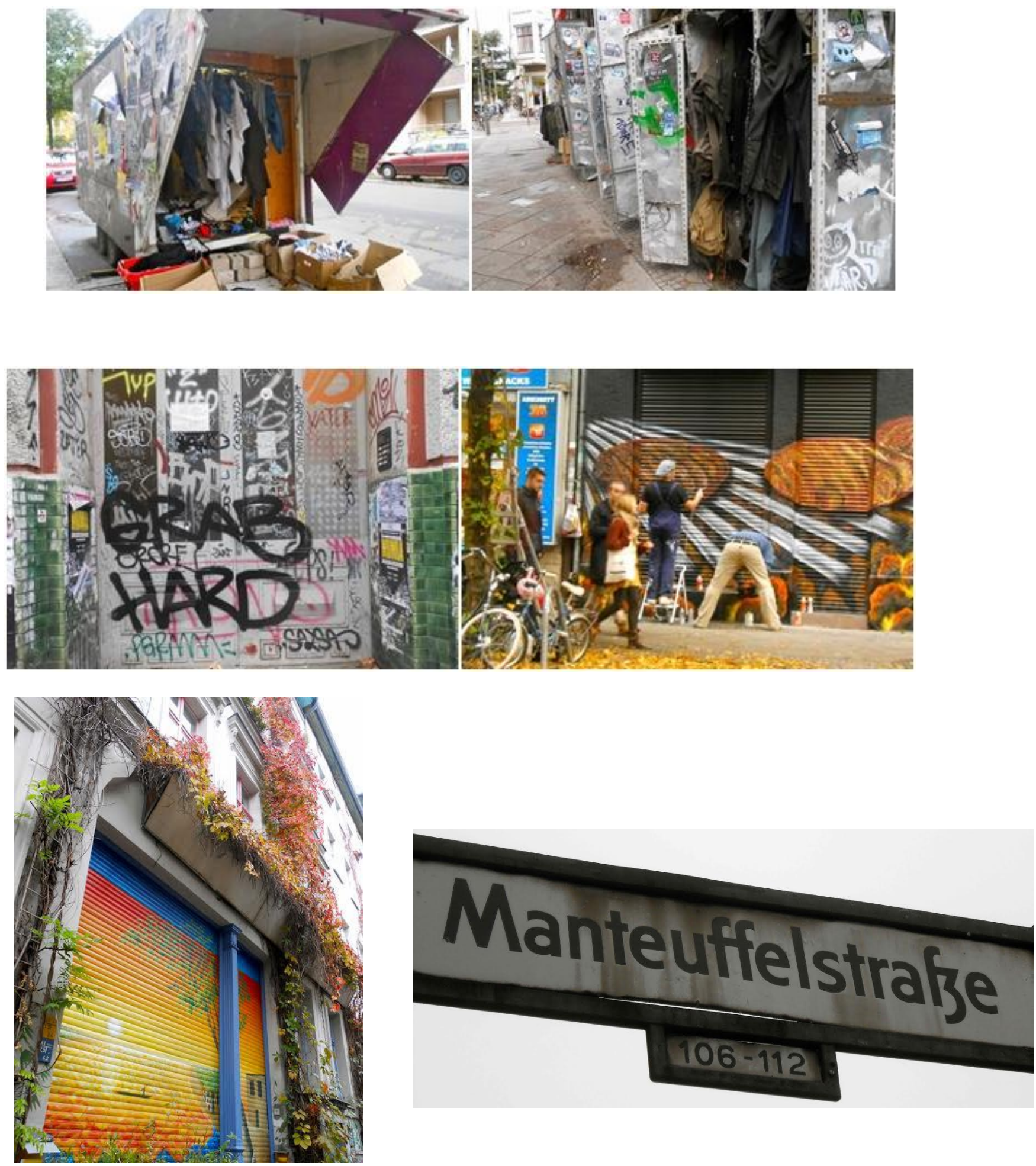

Berlim, outubro 2013. Fotos na rua Manteuffelstrasse, bairro Kreuzberg, onde moramos. Fotos de Cornelia Eckert.

Iluminuras, Porto Alegre, v. 15, n. 36, p.218-268, ago./dez. 2014 
A língua nas ruas que percorríamos no bairro, não era predominantemente o alemão, era o turco. Como etnografar no bairro turco? Mas estávamos na Alemanha, tinha que dar certo. Eu falo alemão, Ana se virava com o inglês, também falávamos em francês e espanhol, e não raro, simplesmente português. A nossa ineficiência em turco, sabíamos, seria um constrangimento para interlocução mais duradoura no setor onde morávamos, mas Berlim é o planeta e Kreuzberg o mundo, e nós apenas mais duas na torre de Babel (Gênesis 11). Sem temer a profecia apocalíptica da desordem, estávamos tão dispostas a esta aventura citadina, que toda dificuldade era abraçada como um aprendizado. A comunicação estabelecida dependia do movimento da rede acionada, dos atores em situação, ou para parafrasear Michel Agier, da cidade relacional, do bairro cultural, da rua situacional de nossas interações (inspiradas em Agier, 2011: 21). As situações rituais na nossa rua, nas ruas do bairro e nos lugares que passamos a etnografar eram tão significativas, que quase podíamos nos restringir a fruição da estética das ruas, a arte citadina.

\section{O documento}

Entramos em um microcosmos incrível. A etnografia nos levou a estas descobertas. Por um lado o bairro Kreuzberg se desvendou para nós como a capital da criatividade rebelde, da arte subversiva, do manifesto testemunhado em grafites e pichações e muitas instituições alternativas. No mínimo três gerações se destacavam, idosos alemães e turcos, jovens de tudo que é jeito, e crianças com seus pais alemães ou turcos. Em segundo lugar, a internet acelerou para nós uma pesquisa-consulta sobre as inúmeras atividades museais, culturais, associativas no bairro. Como não considerar a facilidade da prática da técnica de inserção no mundo etnográfico hoje com esta economia de tempo e esforço intelectual. Em terceiro lugar, há de se considerar que já no Brasil trazíamos sugestões de contatos de moradores em Kreuzberg, em geral amigos de porto alegrenses que hoje moram ou trabalham temporariamente em Berlim. Assim Nina Graeff, irmã de nosso ex-orientando Lucas, Laura a guitarrista amiga de Aline Rochedo nossa aluna, e vários amigos de Roberta Simon, a maioria funcionários na Embaixada brasileira, e outros endereços anotados na cadernetinha que já antecipavam 
alguns ALFAS da nossa network de interlocutores que entrevistamos com vídeo nos três meses de pós-doutorado.

Antes de seguir na rede e no cotidiano pesquisado, mais um pouco de ritual de instalação. A burocracia enfrentada por Ana Luiza não era a mesma minha. Mas eu era solidária, até por que eu era a alemã da dupla. Polícia, banco, prefeitura, isto é etnografia? Interessa, diz Mariza Peirano, observar o Estado em ato, velamos pela "estrutura social e pelo ponto de vista nativo, pelo Estado das regras formais e pela nação dos processos sociais em ação" (Peirano, 2006: 135). Mariza diz isto ao definir como seu tema de investigação os documentos, "papéis legais que infernizam, atormentam ou facilitam a vida do indivíduo na sociedade moderna" (p. 136). Assim, lá vai, petit morceau ethnographique pour Mariza....

BERLIM, 05 DE SETEMBRO 2013, noite

A noite, estudamos os problemas de documentação da Ana Luiza com ajuda da minha afilhada Gabriela (expert em línguas ocidentais) e projetamos sair cedo amanhã para conseguir atestado de residência. Ainda não sabemos se no escritório "Oficio de despacho de documentação' ou se na prefeitura do bairro. Vamos à aventura da burocracia e tirar a temperatura de como a polícia alemã esta tratando o estrangeiro. Até agora, ao contrário da pouca cordialidade vivenciada em Paris com choffeurs e burocratas franceses, os alemães parecem ter tido aulas de atendimento ao turista e buscam ser gentis até quebrando galhos, ou seja, ajudando no velho estilo do jeitinho brasileiro, algo impensável até a pouco tempo atrás. Será que leram Roberto da Matta? Bem, vamos dormir e esperar o dia de amanhã, a aventura policial, da burocracia da conta bancária.

BERLIM, 06 DE SETEMBRO 2013, manhã

Cedo acordamos e fomos na prefeitura do bairro, mais especificamente no oficio administrativo para Ana Luiza solicitar um Anmeldung, um documento que atesta que reside temporariamente no bairro. Importante documento para que ela possa abrir conta no Deutsche Bank para receber a bolsa do governo brasileiro. Eu não solicitei já que vim sem bolsa. Na realidade percebi que estava nervosa, certamente traumatizada pelos pedidos de carte séjour em Paris em uma época que tinha que passar a noite toda em pé para ser atendida pela manhã por uma polícia mal humorada. Por sorte eram muitos os estudantes brasileiros na fila de forma que não estava sozinha. Pegamos novamente o 265 só que desta vez em direção ao sul de Berlim ou centro de Kreuzberg. Olhei rapidamente o mapa da Berlim ocupada e comprovei que iríamos a um ex-território da Berlim oriental em que estava uma torre de controle. Não foi difícil achar o edifício da prefeitura e o anexo administrativo. Vi algumas pessoas entrando ou saindo e observava que eram estrangeiros por suas vestimentas turcas, muçulmanas, etc. Logo ao chegar uma pequena fila se formava. Havia um quadro com vários panfletos explicativos para cada tipo de pedido como auxílio para nascimento, para creche, para viagem ao estrangeiro, auxílios sociais de toda ordem. Quando chegou nossa vez perguntei como conseguir a declaração de moradia temporária. A simpática e magra mulher me deu uma senha e mandou subirmos para sermos atendidas. Passado cerca de 20 minutos nossa senha apareceu no visor eletrônico e fomos recebidos por um rapaz que nos recebeu de forma muito simpática. Provavelmente acostumado em atender estrangeiros logo passou a preencher a papelada e finalizou o rápido processo com 
um carimbo da prefeitura. Ainda nos passou uma documentação para Ana Luiza preencher e entregar duas semanas antes de partir.

BERLIM, 15 de setembro 2013, manhã

Manhã cedo ou não tão cedo... creio que 10 horas da manhã, toca a campainha e estranhamos o som. Já havíamos tomado café. Fui atender e era a campainha da rua cujo som ainda não conhecia. Atendi o interfone e uma voz de homem disse que era a polícia. Perguntei o que queriam e disseram que queriam entrar. Coloquei um casaco e abri a porta da frente seguida da porta do apartamento. Dois policiais vestidos de azul, nem simpáticos e nem antipáticos, polidos, procuram um rapaz, mostraram o nome e disse que o endereço dele era este. Expliquei que era um apartamento alugado, que estávamos aqui há uma semana e não conhecíamos o morador anterior, mas que havíamos alugado de um sistema de internet e o apartamento pertencia a Sara Davis. Pediram para entrar e esclareci que poderíamos mostrar no site a documentação de nosso aluguel comprovando a data de entrada. Ana Luiza que estava trabalhando no computador logo buscou o endereço e o telefone de Sara Davis e passamos para os policiais. Perguntei por que o senhor tal estava sendo procurado. Ele respondeu que o correio avisara que a correspondência dele estava retornando e de que provável ele teria ido embora do país sem entregar a devida documentação de mudança de endereço. Isto provavelmente implica que ele não ficou os três meses como turista, mas ficou como morador tendo se anunciado no sistema administrativo como habitante temporário e não passou duas semanas antes de ir embora como prevê a lei local. Pelo menos é isto que Ana Luiza, minha colega, que ficará quatro meses terá que fazer. Eu fico os três meses permitidos para turistas. Os policiais agradeceram e foram embora.

O dia a dia mostrava que mesmo não querendo, estávamos mergulhadas no tema de Mariza Peirano. Para a autora, os documentos são "objetos de simbolismo complexo... que dizem respeito a racionalidade" e a lógica instrumental. Referem-se também a lógica da participação, que se ambienta na linguagem da solidariedade, da unidade, da ação expressiva, na eficácia dos atos comunicativos, na 'lei da participação"” (Peirano, 2006: 148).

Mas o que experimentamos na prefeitura do bairro foi uma grata surpresa. $\mathrm{Na}$ realidade todos os nossos sentidos estavam preparados para um ritual de humilhação, tal como o experimentávamos em várias ocasiões em Paris ao fazer o documento de estadia (carte séjour). Em especial no ano 1987 com uma média de 24 horas de fila, ao relento incluindo a noite fria, em uma banlieu (periferia da cidade), para 5 minutos de exame com funcionários franceses em que a soberba era irritante. No jogo das aparências, para o funcionário francês o importante é que todos os estrangeiros se sintam humilhados.

Em Kreuzberg, naquela manhã, experimentávamos uma confortável configuração social moderna, aquela do respeito à diversidade, e claro, nos surpreendíamos com a polícia gentil, com os despachos rápidos. Tendo a "papelada" o direito e o respeito estavam garantidos. Éramos cidadãs do mundo. Já os refugiados...bem isto contaremos 
mais tarde. Centenas de panfletos, como matricular seu filho, como obter ajuda da prefeitura do bairro no seu envelhecimento e ter cuidadora de sua saúde em casa, como conseguir moradia, como ter um curso de culinária, como ter aulas de alemão, como ter aulas de música, como aprender a informática, como conseguir documentos, panfletos e mais panfletos, em alemão, em turco. Uma aula de gestão pública no bairro Kreuzberg. Para não entrar na fila para o documento de permanência temporária, é necessário agendar na internet. Ana Luiza não seguiu esta orientação e teve que reviver a espera na fila ao relento em frente do edifício público. Sem bolsa de estudos eu me livrara das mazelas burocráticas. Do meu lado, enfrentava mais rotineiramente as disciplinas do curso no Instituto Latino Americano. Situações que nos tiravam do bairro, nos colocavam em outros percursos de ônibus, outras linhas de metrô, outras redes e que aqui e acolá, rendiam mais um informante.

\section{O melhor museu do mundo}

Localizado por internet, FHXB Friedrichshain-Kreuzberg Museum, o melhor museu do mundo é o do nosso bairro. Não vamos nos alongar por que já escrevemos um artigo sobre esta experiência, $\mathrm{O}$ seu bairro tem um museu? Foi escrito a pedido. Por hora interessa insistir de que não se trata de uma proposta que compartilha dados factuais de uma história de bairro, mas partilha sentidos e representações semânticas, uma aula sobre o tempo e a cidade. 

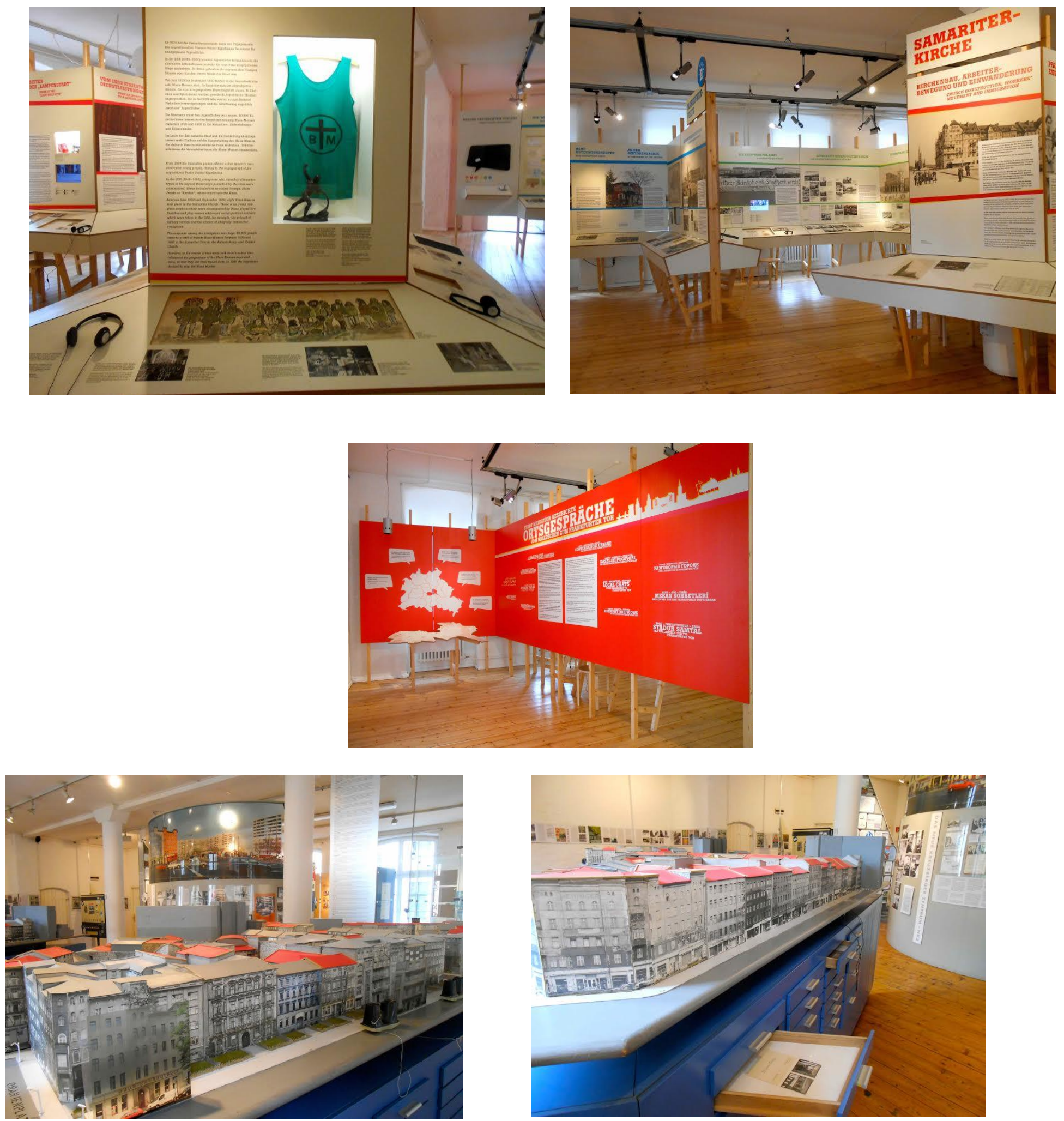

Berlim, outubro 2013. Museu do Bairro Kreuzberg. Fotos de Cornelia Eckert

Iluminuras, Porto Alegre, v. 15, n. 36, p.218-268, ago./dez. 2014 


\section{SO 36, o pior lugar do mundo?}

Rotina diária. Percorrer o bairro, caminhar a pé ou de ônibus. Não há como negar que a curiosidade do percurso do muro construído nos inquietava. Como podia a paisagem ser agora tão homogênea? Certamente a orientação de Gilberto Velho em buscar no que permanece e no que se transforma na ambiência etnografada, é nossa motivação. O exercício implicava em ver muitas imagens nos livros comprados, investimos muito nisto, Inside Kruezberg de Michael Hughes, Stillstand un Bewegung, Menschen in Kreuzberg, Fotografien aus den 70ern und 80ern de Ellen Rohnen e Erik Steffen, Berlin am Kottbusser Tor e Berlin Kreuzberg SO 36 de Peter Frischmuth, por exemplo, que revisita lugares que havia fotografado nos anos 80 após a queda do muro. O autor contrasta o preto dos anos chumbo com o colorido dos anos sexy, nos provoca esta atenção aos rastros temporais nestes circuitos pelo bairro.

Mas o mais importante era percorrer o bairro, a cada dia um fragmento, um pedaço, uma franja, uma dobra da territorialidade relacional. Algumas caminhadas tinham a intenção de chegar nos lugares de sociabilidade cultural, o já citado museu, a igreja luterana com um mini museu sobre o muro de Berlim, sobre a SO36, uma história enigmática, o centro cultural Bethanien na Mariannenplatz.

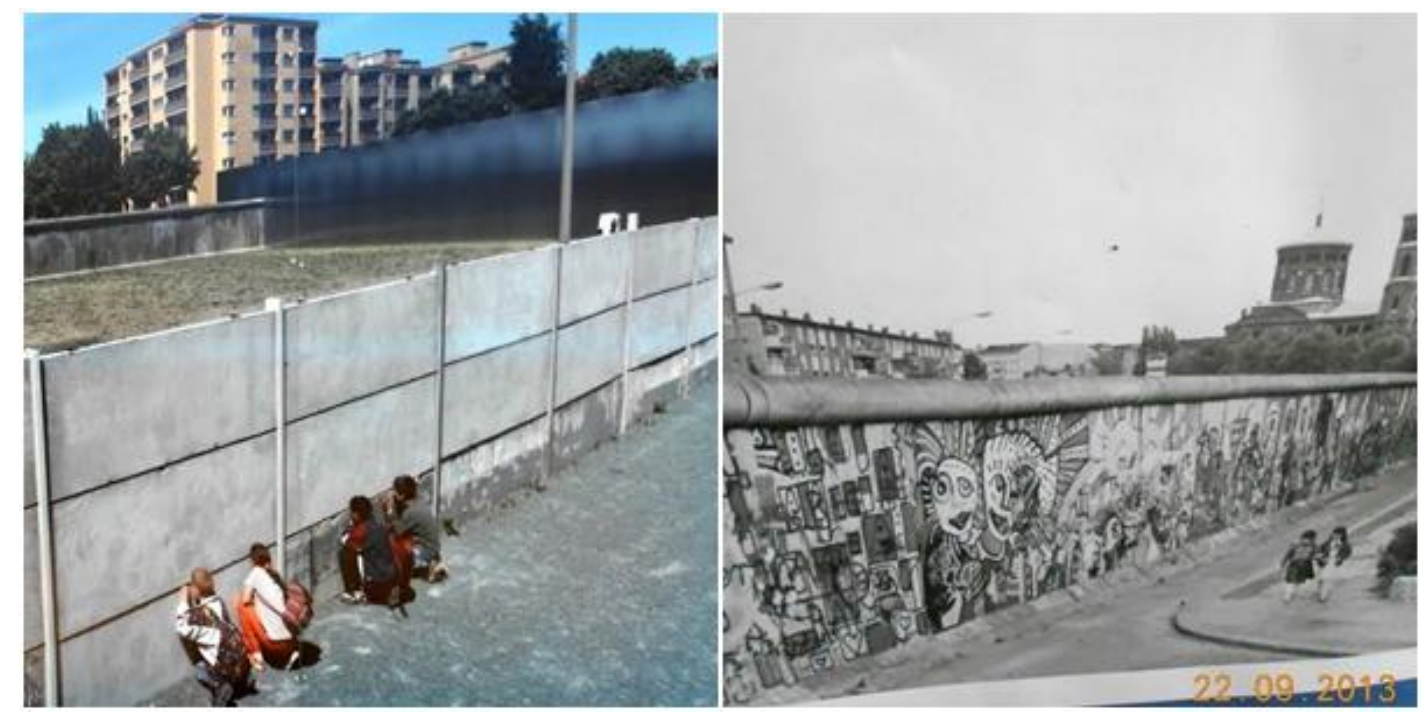

Berlim, novembro 2013. As fotos sobre o muro de Berlim no bairro são do acervo da Igreja Luterana São Tomas. Reprodução autorizada. 

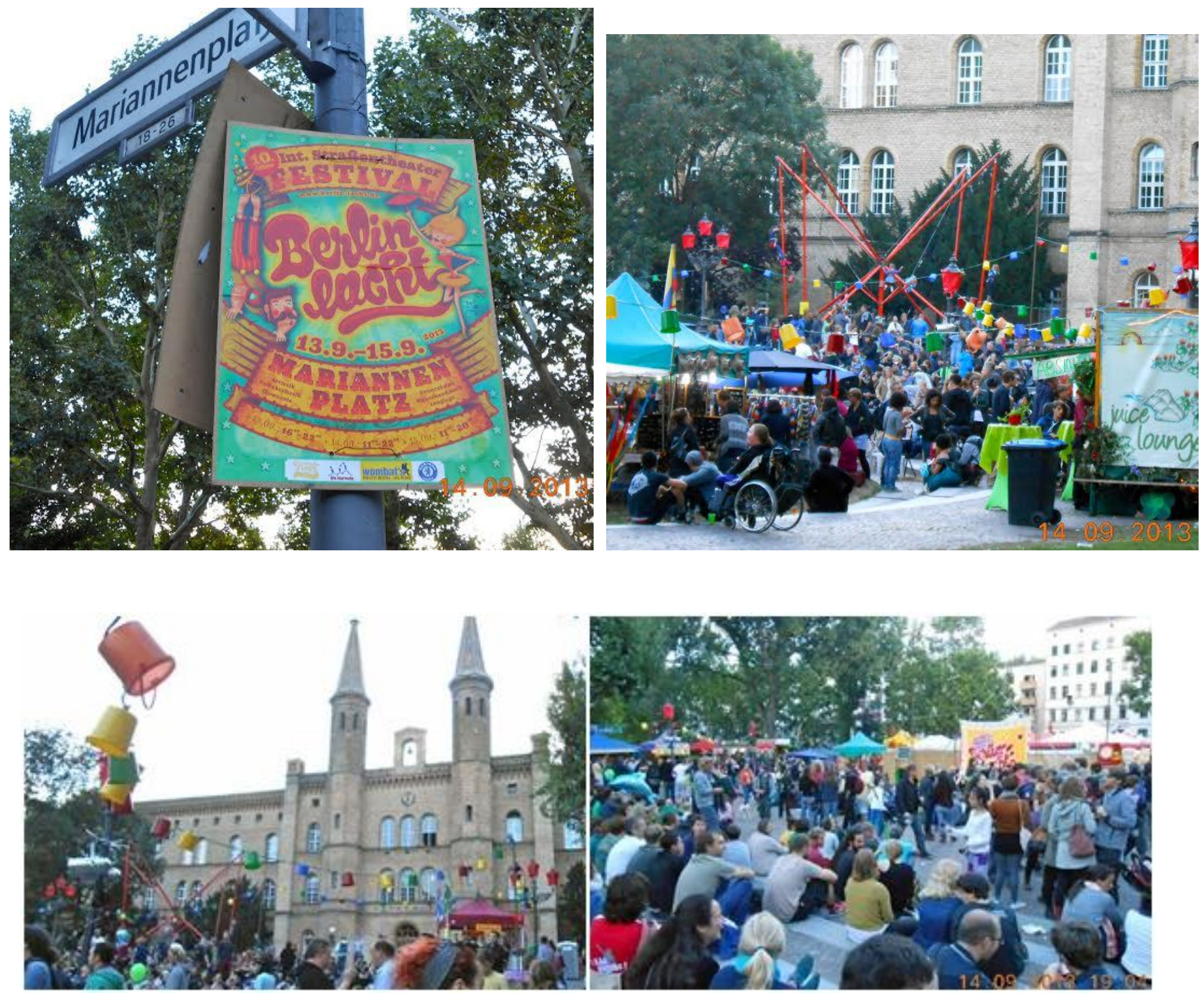

O centro cultural Bethanien na Mariannenplatz. Fotos de Cornelia Eckert

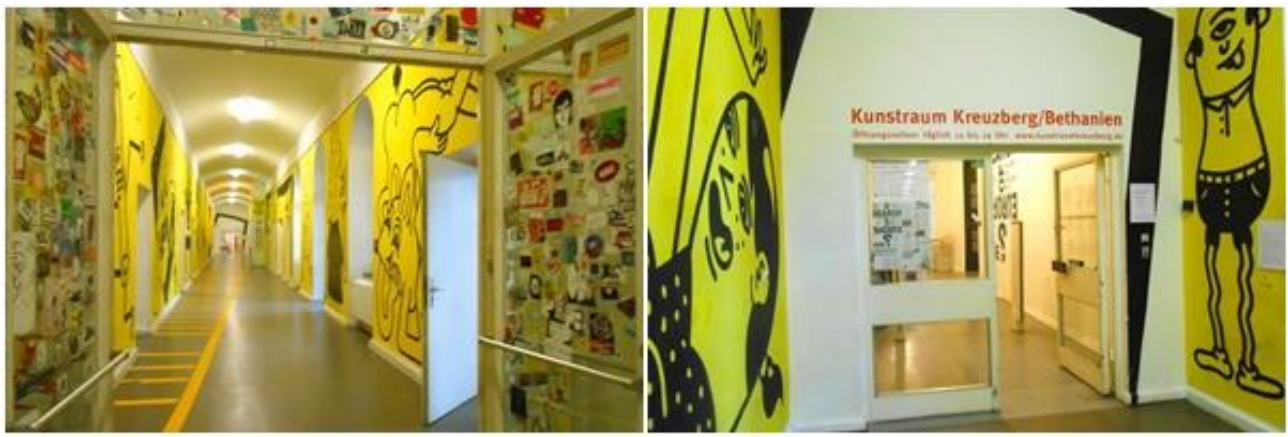

O centro cultural Bethanien na Mariannenplatz. Fotos de Cornelia Eckert

Iluminuras, Porto Alegre, v. 15, n. 36, p.218-268, ago./dez. 2014 
Cada saída era com mapas. Em geral dois eram constantes. Um que representava a Berlin dividida nos quatro territórios (francês, inglês e americano e claro, o socialista alemão) o outro atual. O mapa desenhava uma linha irregular e aparentemente sem sentido. Ana Luiza, sua irmã Maria e eu brincávamos com a ideia de que os construtores deveriam estar com sono ou bêbados na noite em que foram obrigados a construir as pressas um traçado ilógico. Nossa rua por pouco não estava no dito lado oriental. $\mathrm{O}$ bairro, a exemplo do vizinho Mittle, foi rasgado pelo muro de tal deforma que esteticamente predominavam cantos, becos, emprestando às incertas zonas, a identidade de guetos seculares. Mesmo os habitantes da zona leste se sentiam encurralados, informa Volker Viergutz no livro O muro de Berlim 1961-1989 (Viergutz, 2013: 64). A zona SO 36 que inicia no centro, recebe o estigma de marginal. A área tinha importante parque industrial mas em termos imobiliários, era uma região desvalorizada pela proximidade do muro. Desta feita, foi um território de construção de edifícios sociais para hospedarem a grande horda de imigrantes turcos chamados pelo governo alemão para assumirem os trabalhos nas indústrias em face da perda da força de trabalho do alemão oriental.

Não havia como reduzir esta etnografia de deslocamento na rua em uma coleta de dados folclóricos, cada lugar, cada traço, cada episódio, nos empurrava para um tempo público múltiplo, errante, fluido e líquido.

No dia em que fomos na prefeitura, no ônibus 265, assistimos a uma cena que nos descortina a intriga do tempo, dos segredos na SO36. O ônibus na Alemanha como sabem tem uma política de acessibilidade para os cadeirantes, idosos, gestantes, etc. Para o acesso do cadeirante, o motorista desce do ônibus, se dirige a porta do meio, e com uma ferramenta abre uma tampa que se desdobra transformando-se em uma rampa. Em uma parada um velho senhor aguarda o ônibus com um carrinho carregado de papéis lembrando um coletor de Porto Alegre. O ônibus para em frente a um hidrante e o velho discute com o motorista sobre a barbeiragem. O motorista havia calculado mal que o velho conseguiria entrar com seu carrinho sem a rampa e ainda mais com aquele obstáculo. O velho entra no ônibus reclamando e tropeça. Eu o ajudo com o carrinho e ele começa a conversar comigo e em 5 minutos passa a contar fragmentos de sua biografia. Começou agradecendo e diz que estava levando aqueles jornais para uma empresa de reciclagem. Abaixa a voz e diz que eram papéis do 'tempo dos nazi', que 
ainda havia muitos jornais para carregar. Que era húngaro mas já havia se naturalizado alemão, que agora era um verdadeiro alemão. Se sentia cansado, com dor nas costas, pois em cada carregação levava de 89 a $90 \mathrm{Kg}$. Perguntei se ele já não podia descansar e se aposentar. Respondeu que já era aposentado mas que era o jeito de ganhar a vida. Chegamos ao nosso destino. Quando a porta do meio abriu ele mesmo puxou o tampão para descer. O motorista ficou furioso, saiu xingando, dizendo que esta era a tarefa do motorista. Nós também havíamos descido e aproveito para perguntar para ele, onde ia. Ele respondeu que ia na empresa, a de reciclagem, justo no final da nossa rua. Segui seu movimento com os olhos e mais tarde fotografei o depósito. Quantas camadas de tempo naqueles papéis impressos? Muitos episódios como este anotei em diários, mas já este quase-personagem nos evoca os entrelaçamentos de acontecimentos no bairro.

\section{Bairro polifônico}

Minha mala esta arrebentada. Busco um sapateiro na minha rua. $\mathrm{O}$ senhor que me atende não fala alemão. Somente turco. Mostro o rasgado da minha mala e ele desenha no papel uma linha até a esquina, faz a curva e com um X mostra o que entendi ser uma outra sapataria. Agradeço em alemão e sigo os passos indicados pelo meta-mapa. De fato era uma outra sapataria. Porta fechada como quase tudo na Alemanha, mas abrir a porta é seguido do sinal de uma campainha com som simpático. Na sapataria duas turcas me recebem, senhoras cobertas pela hejab, conversavam. A que esta na máquina de costura própria para couro me atende. Fala alemão e entende meu drama doméstico. $\mathrm{Na}$ esquina da rua paro para um café com leite. A moça que me atende pergunta em inglês o que desejo. Na padaria compro pão turco.

Estava entusiasmada. A tarde faria uma entrevista com uma brasileira casada com um alemão. Fernanda era amiga de Roberta, minha aluna. Não era moradora do bairro, mas sim na vizinha Neukolln em um edifício de esquina em frente ao imenso parque público e antigo aeroporto de Tempelhof. Ela me espera no café Engels, novamente a língua de atendimento é o inglês. $\mathrm{O}$ dono era inglês e as atendentes atendiam nesta língua. A entrevista durou toda a tarde. Fernanda narrou sua trajetória bem como sua experiência de viver no bairro. 


\section{$O$ centro da cidadania}

A tarefa diária das compras era revezada. As compras no supermercado. Pego o carrinho de compras e me preparo para contornar o quarteirão já que o supermercado é exatamente nas costas de nosso edifício. Saio de casa e espio a pizzaria ao lado, propaganda de Pizza mediterrânea. Italianos? Gregos? Uma pequena equipe sempre trabalhando nos fornos expostos por um vidro-vitrine. $\mathrm{Na}$ esquina da nossa rua o restaurante italiano que iríamos conhecer mais tarde. Na outra esquina o restaurante alemão em que jantamos no primeiro dia cansadas e com fome. No cardápio, brockworst, Kartoffelsalat und Bier. Sigo meu destino do dia. Sempre nos revezamos nas compras e lá chego. Puxo do meu casaco uma pequena câmera fotográfica, e misturo a intensão das compras com fotografias. $\mathrm{O}$ mercado fica em um centro comercial, ou melhor centro cultural, ou melhor centro social. Certo desisto, um centro holístico e dialético onde tudo pode acontecer. O mais certo é que é um Marktplatz fur Kultur, um mercado para cultura.

$\mathrm{Na}$ entrada, um restaurante. Sigo o que seria um trajeto individual quase que diário. Primeiro fotografamos os bichinhos presos esperando seus donos. Só olhar, nada de tocar. Passado o portal, paro para ler o grande mural com a programação da semana: múltiplas oficinas, cursos e palestras. A direita uma padaria, mas nas banquetas próximas sempre homens e mulheres em geral idosos tomando cerveja. À esquerda uma grande loja. Tudo por baixos preços. A loja é voltada para um público de baixa renda, como nós. À direita, enfim, o supermercado, mas o que queremos contar é o que existe a mais neste pavilhão, mercado, casarão. Markhalle Neun: um restaurante de comidas alternativas, ora vegetarianas, ora slow food. O mercadão, no entanto, é mais do que isto, é um centro de encontros, de troca de ideias, de consumo de produtos de todos os países (feiras esporádicas), de exposição de arte e de festivais de comida, de oficinas para crianças, etc. Só este lugar dava uma tese. Língua oficial? Todas. Também lugar de culto ecumênico. E foi neste mercado que assisto em novembro ao culto luterano de festa da colheita. 

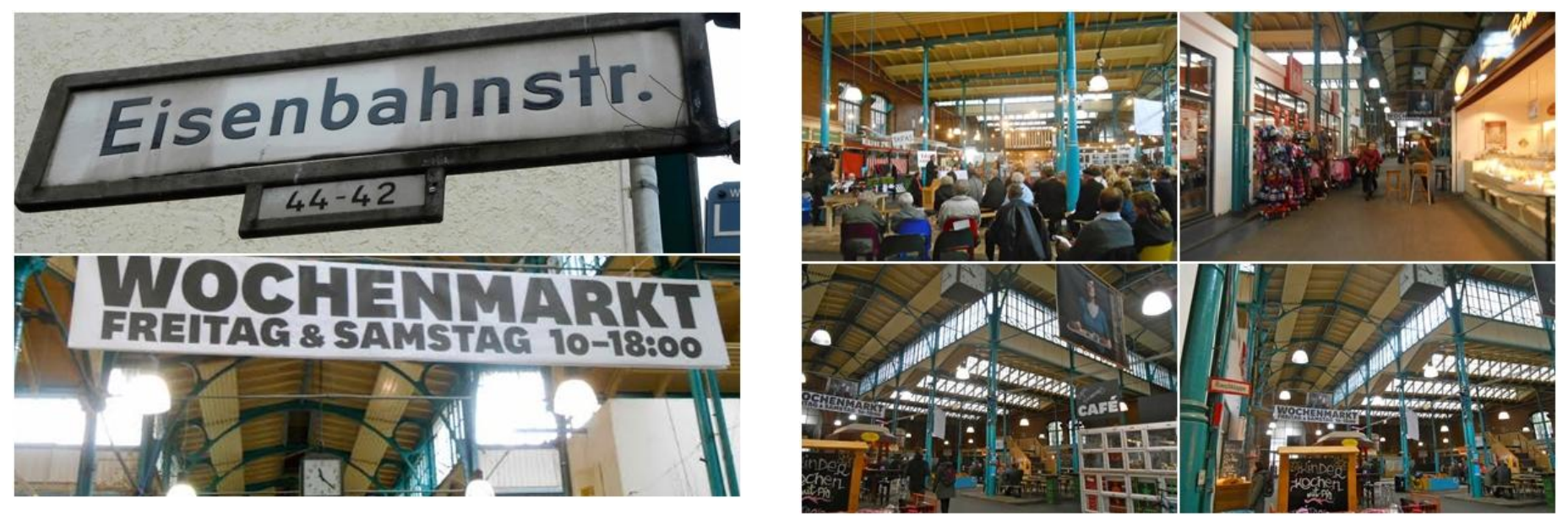

Berlim, setembro, outubro e novembro 2013. Fotos de Cornelia Eckert.
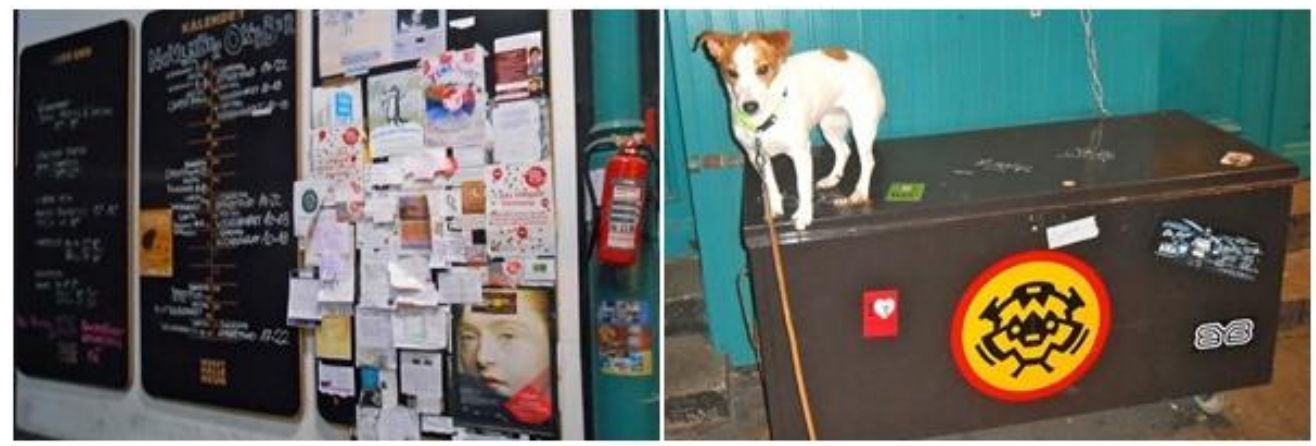

Berlim, setembro, outubro e novembro 2013. Fotos de Cornelia Eckert.

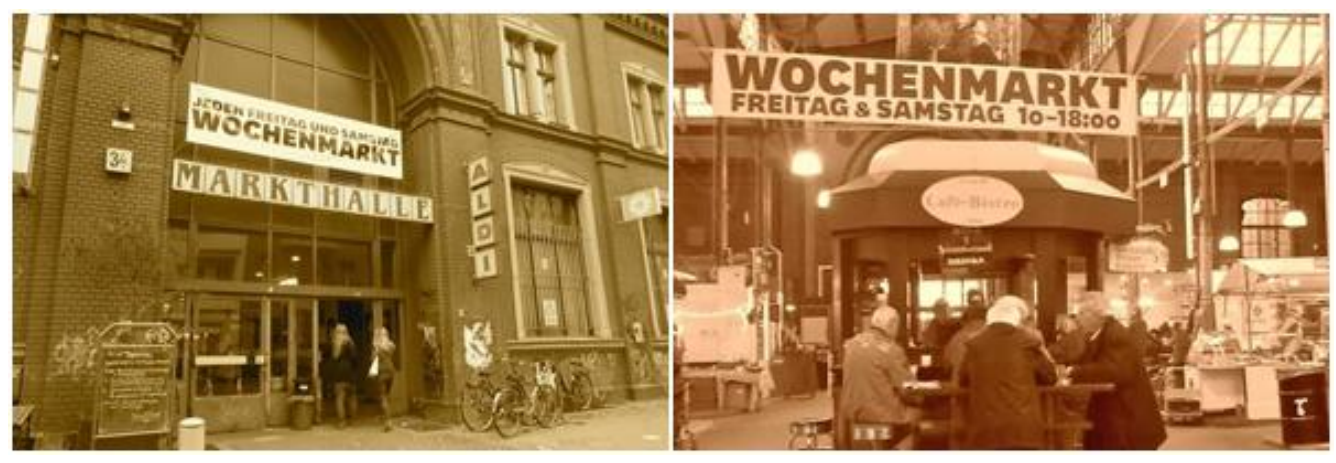

Aos poucos, acostumei-me em ver os habitués. Ficava imaginando quem seria o gerente. O cozinheiro chefe, eu reconhecia, um jovem alemão com a touca do movimento reggae, mas a equipe mudava sempre. Algumas vezes experimentamos comer ou beber no local. Sobretudo nas quintas, ou sextas, ou sábados à noite quando 
éramos incentivadas por cartazes, panfletos, folders para frequentar o fórum do mundo, o mercado das nações, os workshops. O público mais frequente nestas ocasiões era uma geração com média de 20 a 40 anos. Os pais ficavam nas longas mesas bebericando e as crianças nos brinquedos aos gritos expressando suas alegrias.

A etnografia deste lugar se estendeu pelos três meses e temos muito material para analisar. Um pequeno trecho do diário de 21 de setembro 2014, sábado pela manhã transmite o impacto deste centro para nosso cotidiano.

Percorri as várias bancas de produtos coloniais, legumes, verduras, chás, carnes, padarias, quinquilharias... muitas floristas. Perguntava algo aqui acolá sem verdadeiramente buscar uma interação e juntei material fornecido pelas bancas e pelo mercado.

A maior propaganda se refere a um domingo dia 3 de novembro 2013 das 11 h as 19 $\mathrm{h}$ com entrada franca e um encontro do slow food Berlim com promoção da Cheese Berlin, queijos de todas as regiões estarão expostos. Segundo o livrinho Citizen art days, a partir do dia 27 de setembro ate 6 de outubro o mercado publico não será apenas um mercado mas um lugar de ideias e trocas. Chama-se de Citizen Art Days, Dias da arte cidadã:

Diz o livrinho:

Queridos berlinenses

Queridos artistas e amigos da arte

Venha nos dias da arte cidadã

Crescimento, sustentabilidade, qualidade, transparência, participação, diversidade. Como podemos produzir de forma sustentável alimentos responsáveis? De onde é que eles vêm? Quem os faz? Produtores recebem um preço justo? Tem qualidade? Como é que vamos conseguir uma boa comida que seja acessíveis para todos - $e$ sem luxo? Como podemos cozinhar algo agradável para comer? O mercado novo se coloca como um lugar de culturas alimentares é a expectativa de um ... setor cultural. Esperamos os visitantes dentro dos dias de arte cidadã.

\section{As bicicletas}

Berlim 8 de setembro 2014

Chegando em casa, percebo com mais atenção a frente do nosso edifício, os dois bares que cercam a nossa entrada. Acho que a pizzaria definitivamente é de turcos. O outro é bar com publico jovem que jogam futebol de mesa ou bebem sentados na frente na calçada, e claro, fumam muito. O numero de bicicletas estacionada é enorme. Também não é diferente a entrada do nosso edifício, lotado de bicicletas estacionadas. De forma que cada morador deve ter a sua ou mais. Como a grande maioria dos edifícios o nosso não possui garagem para carros, suas construções datam de antes da popularidade dos carros. Carros em Berlim? Há muitos mas não conheci ninguém que o tivesse. Todos se deslocam de bicicleta, onibus e metro. De qualquer forma a bicicleta é o meio de transporte mais privilegiado da cidade e tem uma pista só para esta locomoção. Para um estrangeiro não acostumado com este transporte, facilmente pode ser atropelado como aconteceu com Maria uma vez e com Ana em outra ocasião por estarem se deslocando no espaço das bicicletas. Só podiam ser brasileiras. 


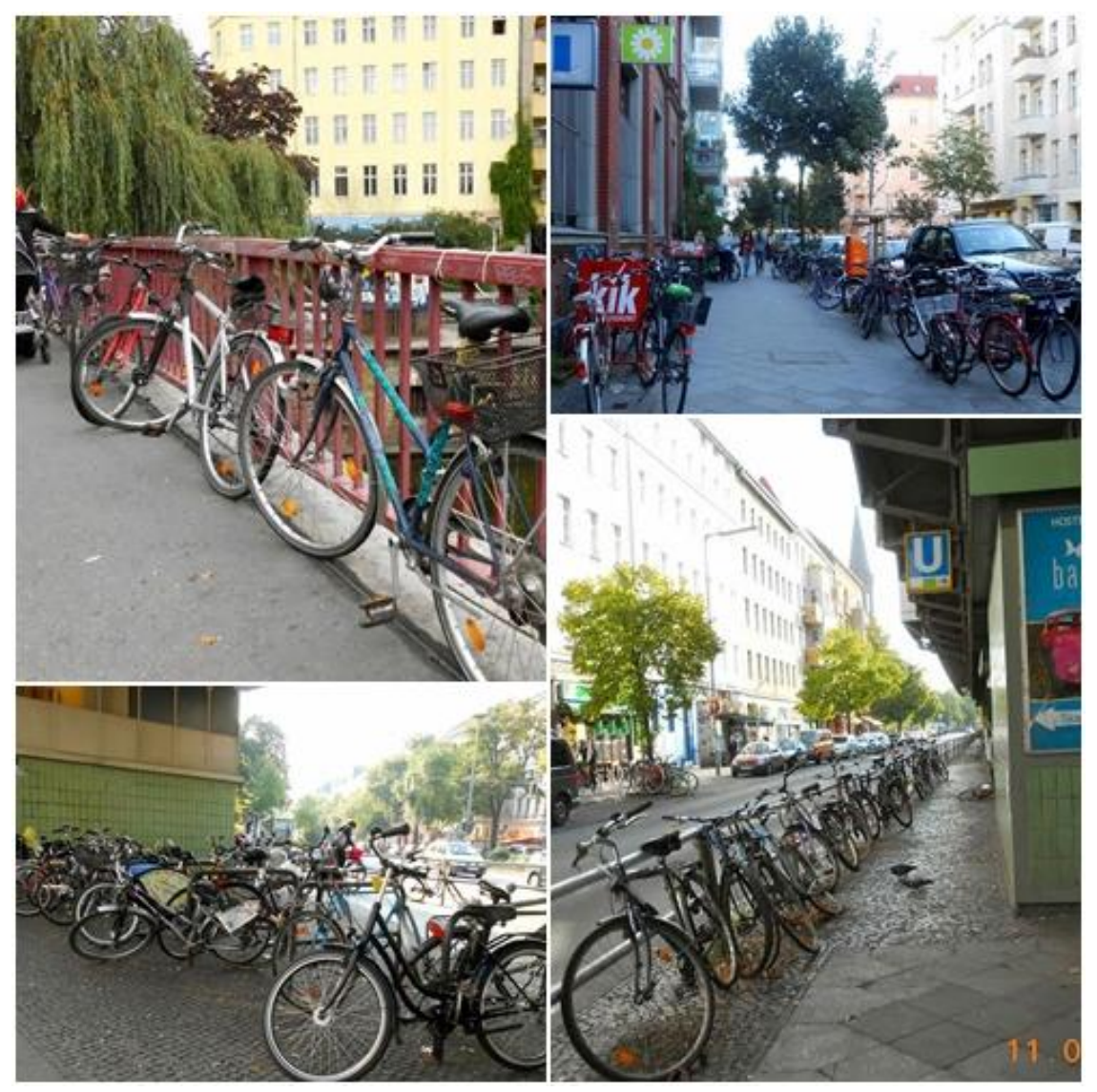

Berlim, setembro e outubro 2013. Fotos de Cornelia Eckert

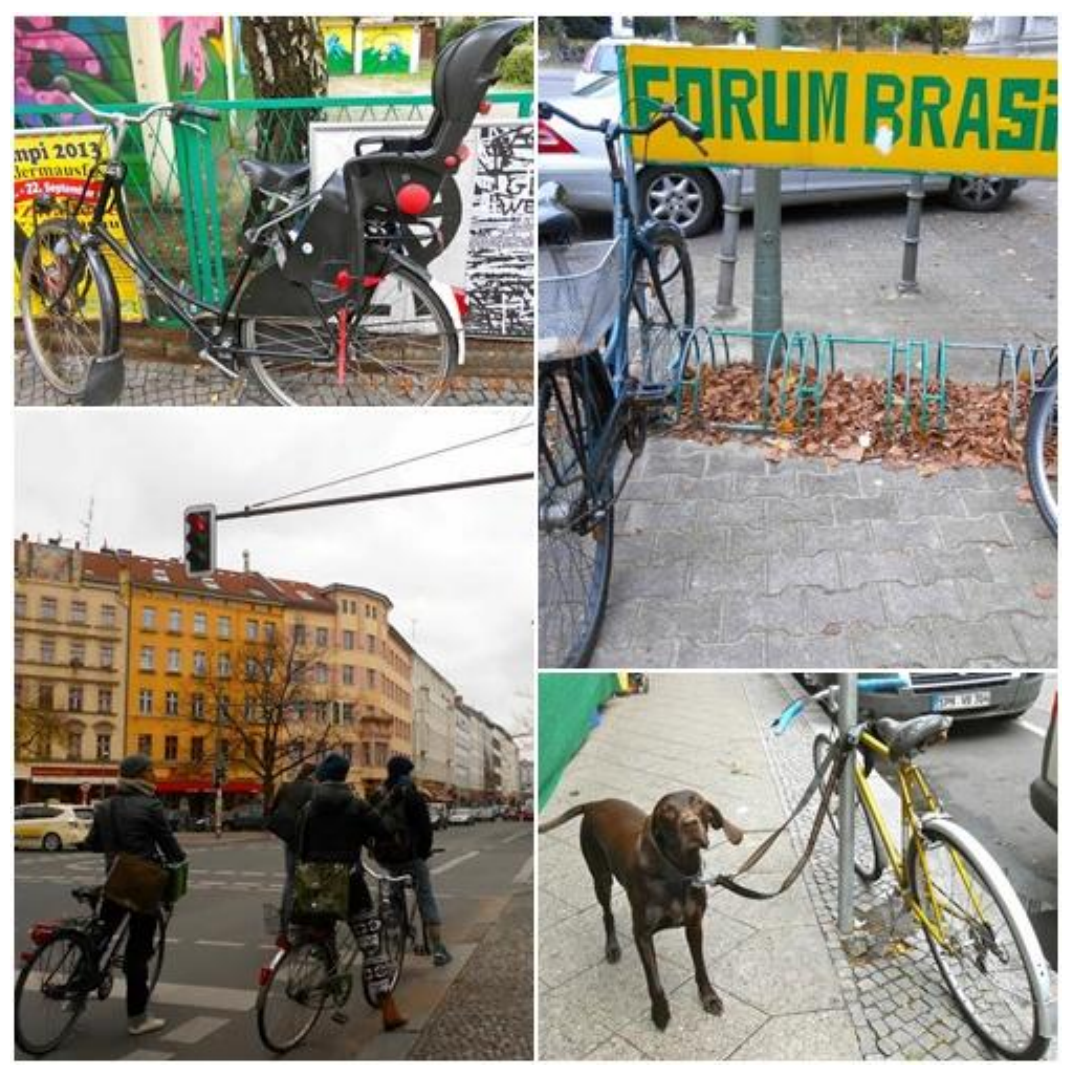




\section{O veado, o marreco e o coelho enforcados}

Pergunto ao funcionário do Museu se ele mora em Kreuzberg e responde que não, no bairro vizinho, mais charmoso Neukolln. Ana, Maria e eu perguntamos sobre os livros com grafites e pichações. É 21 de setembro 2014 e iniciamos um debate sobre a estética do bairro. Ele protesta ao eu lhe perguntar sobre a grafite no bairro. Responde como se eu tivesse dito uma heresia: "Sujeira", diz ele, "isto não é city art, não é grafite". Para o interlocutor, de fato predomina na cidade a arte de grafite, algumas intervenções tendo obtido sucesso internacional. Insiste que temos que comprar o livro sobre arte na cidade para reconhecer os murais mais famosos. Mas de novo, declara, "este bairro tem é intervenções-sujeiras", o que entendo ser as pichações de múltiplas formas, sobretudo nas portas dos edifícios.

Resolvo fotografar a nossa rua todos os dias, Manteuffelstrasse - mas, cuidado, os nomes das ruas podem se repetir de um bairro para outro. Assim, é necessário sempre identificar primeiro o bairro. Na nossa rua, de um dia para outro, pode haver alguma mudança, se não são as pichações noturnas, podem ser os grafiteiros contratados ou os funcionários colando cartazes nas paredes dos edifícios. Não duram muito, na sua forma original, logo outros cartazes são colados. As sobrecolagens são permitidas e para muitos artistas uma prática artística de intervenção ou simplesmente mais uma colagem fixada sobre a outra. Nada de limpar a colagem do dia anterior, tudo pode se transformar em arte, desde que é claro, previsto no plano administrativo. 

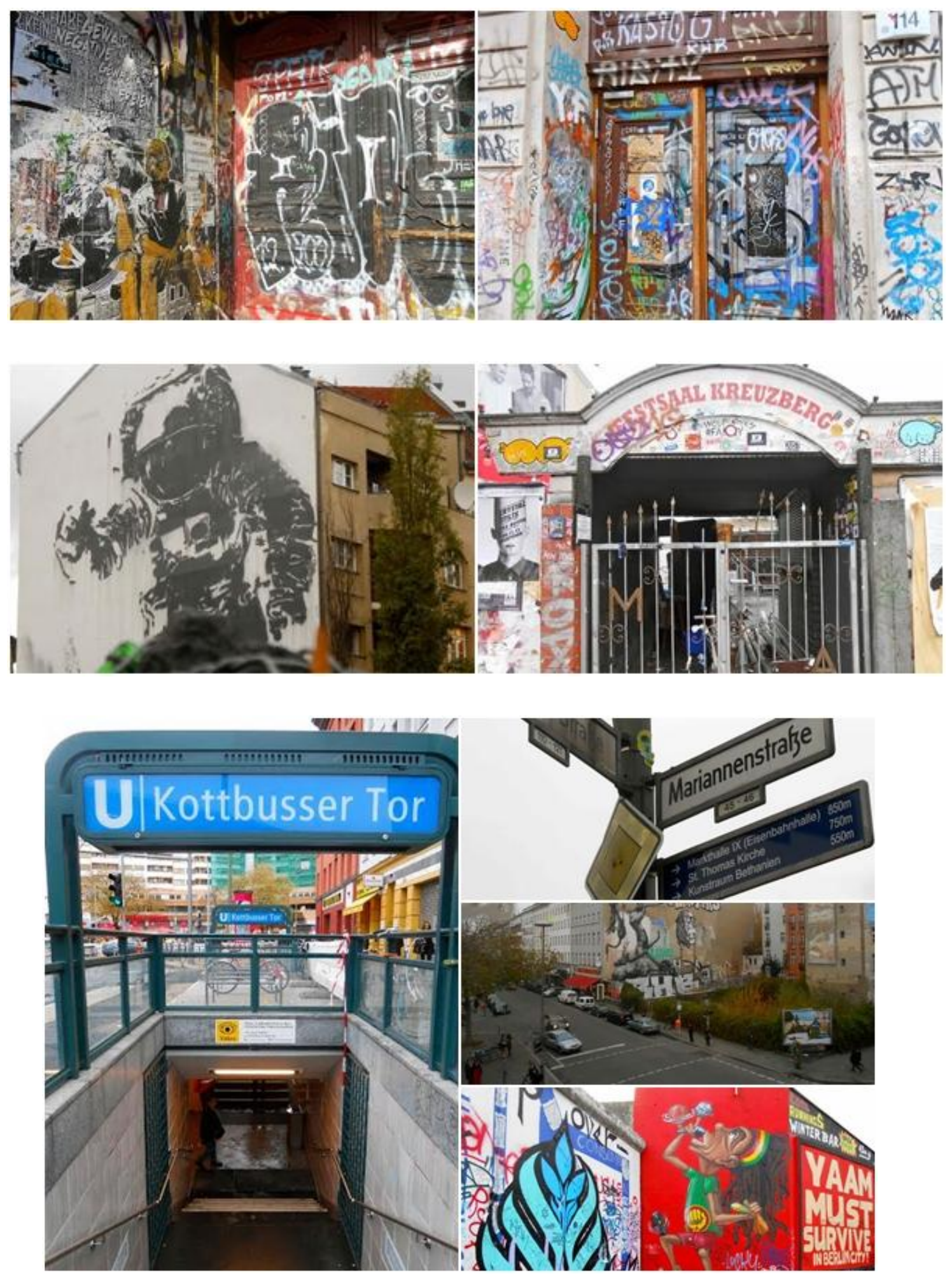

Berlim, outubro e novembro 2013. Fotos de Cornelia Eckert. 
A cada dia um grafo novo, mais uma porta pichada, ou parede, ou muro. Alguns mais permanentes. Nos primeiros dias no bairro ainda estranho muito, não gosto. Aos poucos o movimento de acompanhar as intervenções vai me afetando positivamente. Fico instigando Ana de que, em nossas entrevistas, temos que pensar nos atores dessas intervenções. Mais um obstáculo, como etnografar os personagens noturnos do ato de pichar? Não observo câmeras nos edifícios como no meu bairro no Brasil. O que não quer dizer que não tenha, mas não me aprofundo sobre o big brother berlinense. Sem disposição para aventuras noturnas, nem idade, nem vontade para isto, seguimos na nossa etnografia nas ruas do bairro apenas diurna.

Diário 27 de setembro 2013. Todos os dias vemos o veado, o marreco e o coelho enforcados na esquina da Manteuffel com a Orianenstrasse/Wienerstrasse. Pesquiso e registro que é obra de um nativo de Ghent, Bélgica, chamado(a) ROA. Os quadros são exclusivamente desenhado em uma cor preto, branco ou cinza conservador paleta, e são pintadas principalmente com latas de spray aerossol. ROA trata extensivamente com os temas da morte e decadência, retratando rotineiramente mortos ou em decomposição de carcaças de animais que refletem a natureza transitória da vida humana e da arte de rua que é inerentemente impermanentes devido à sua exposição aos elementos. O mural no Oranienstrasse foi encomendado pelo Skalitzers Arte Contemporânea em 2011. http://news.artnet.com/artworld/berlins-top-5-graffiti-and-street-art-paintings-12183

$\mathrm{Na}$ esquina o destino em geral é pegar o metrô na estação Gorlitzer. Mas nem sempre, não raro o meu programa solo ou com as meninas é dobrar e simplesmente caminhar na Orianenstrasse. É a minha rua predileta no bairro. Preferência de caminhar até o coração turco, o Kottbusser Tor onde fica também o museu do bairro, a biblioteca do bairro, o centro comercial do bairro, o que mais? A sede do único deputado eleito no dia 21 de setembro 2013 do Partido Verde. Aliás, falando nele. Eu o conheci no dia 21 de setembro 2013. Após um dia de pesquisa no museu, a noite de sábado era de calor o que era um ótimo ambiente para a etnografia das múltiplas formas de sociabilidade na rua na Orianenstrasse. A noite na realidade era especial, vésperas de eleições, a Orianen era palco de demonstrationen. O movimento nas ruas estava intenso. Um grupo vestido de vermelho distribuía brindes, eram os Links (esquerda). Não havia nenhum policiamento, tudo em paz. Me misturo um pouco para ouvir os comentários. A candidata à deputada do partido de esquerda distribuía propaganda eleitoral rodeada de militantes. Sentamos em um bar com mesas e cadeiras rústicas na rua. O candidato do Partido Verde se aproxima, fico entusiasmada. Ele distribui "santinhos". Digo que 
votarei nele e ele agradece. Sigo fixa em seus movimentos. Ele esta sozinho, sem militantes no entorno. Termina de distribuir os materiais, pega uma bicicleta e se afasta pedalando. Mais tarde confiro, foi o único candidato do Partido Verde eleito.

No outro dia, nada melhor do que tirar a temperatura do dia das eleições caminhando pelas ruas. Como no Brasil, dia de eleições, pouco movimento na rua. Aproveito para fotografar o grafite de um astronauta desenho de 2007 (22x14m) de Victor Ash na Mariannenstrasse ${ }^{4}$. Final da tarde vamos para Potsdammer em busca do movimento em função das eleições. A agitação com barracas e música nos animaram. Mas era uma festa para o dia das crianças, 22 de setembro. Aproveitamos o evento e nos divertimos assistindo o show da banda de rock com músicas que embalavam a criançada e os adultos.

\section{A arte da resistência e a resistência da arte}

Em 1989 o natal se aproximava. Eu morava em Paris para o programa de doutoramento. Lembro as cenas da queda do muro que assisti em uma pequena televisão preta e branco no apartamento alugado. As notícias do movimento eu não perdia pelo radio FranceInfo. Queria ir, queria muito ir. Criar coragem, pegar o trem e estar lá. Pela primeira vez em minha vida queria estar encima do muro. Mas como? Dinheiro apertado, trabalho de campo caro, e uma tese para avançar.

É deveras estranho encontrar nos fundos da Thomaskirche uma cabana no meio de uma pequena área com horta mal cuidada. Simulacro de uma cabana em estilo hippie, com bandeiras diversas. Estas parecem indicar ser de algum partido de resistência, no meu imaginário. Passo pelo lugar em várias ocasiões. Observo o movimento e percebo que os varredores da rua entram, parecem tomar uma água e saem. Algo como um QG para o intervalo. Talvez seja apenas um lugar de descanso dos funcionários de limpeza urbana. Mistério? Na primeira saída de campo sim. Mas na medida em que pesquisamos, o enigma se dilui e conhecemos a história de um camponês turco que resolveu fazer uma horta ao lado do muro no lado ocidental.

\footnotetext{
${ }^{4}$ Consulta ao portal http://news.artnet.com/art-world/berlins-top-5-graffiti-and-street-art-paintings-12183, dia 22 de setembro 2013.
} 


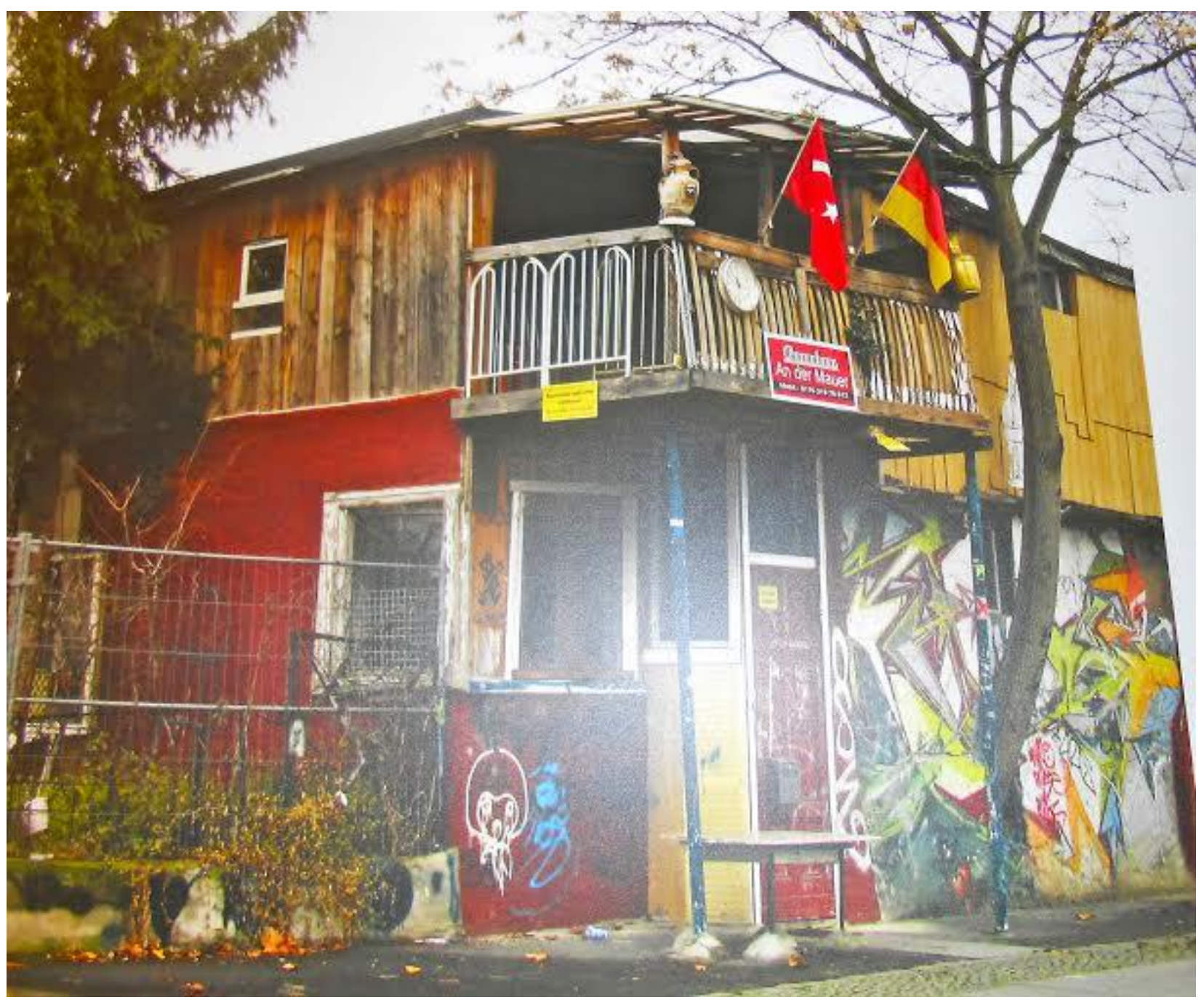

Berlim, 17 setembro 2013. Do acervo da igreja São Tomas devidamente autorizada pelo guardião. Foto de Cornelia Eckert.

Enquanto o governo democrático construía uma impressionante muralha, o ancião e sua esposa, transformavam o lugar perigoso e abandonado em um frutífero jardim. Importa lembrar que o muro teve quatro gerações tecnológicas e ver isto no museu Centro de Documentação do Muro de Berlim é sempre impressionante. Neste centro, pode-se pesquisar tanto as imagens e documentos quanto se pode percorrer um longo museu a céu aberto com restos do muro e apreciar uma expografia com sistema de som com acontecimentos narrados. 
Berlim, 25 de setembro 2013, quarta feira. Pesquisa Dokumentation Berliners Mauer.

A pesquisa de campo hoje foi concentrada na visita ao acervo do Arquivo Estatal de Berlim. Fomos de ônibus, metro, ônibus. Esta instituição é composta de duas estruturas de pesquisa. Uma de visitação, propriamente dita, com museu a céu aberto em que estão expostos os restos das estruturas de muros bem como de outros sistemas de controle e fortificação para evitar a fuga e para firmar a separação territorial da DDR e da West Berlim. Cada equipamento apresentado é acompanhado de uma estrutura áudio visual com material biográfico de refugiados e envolvidos nos processos de fuga ou de assistência aos refugiados, bem como de intelectuais e religiosos envolvidos na luta pelo espaço da cidade, pela permanência da igreja que foi demolida, restam os destroços, com ênfase na biografia dos mortos nas tentativas de fuga. A biografia de cada um era apresentada nos diversos sistemas audiovisuais espalhados no parque bem como homenagens de placas e esculturas.

No centro de documentação tivemos acesso a material fílmico que assistimos e podemos também adquiri-los para pesquisa. Além disso tivemos acesso a material bibliográfico aberto a consulta e também para compra.

Mas foi em especial na igreja na Mariannenplatz que conheci a história do muro em Kreuzberg e as biografias de resistências. Perto da igreja, nos fundos, o muro passava. No lado republicano a intervenção de dizeres, pinturas, signos e sinais não podiam ser mais claros, Die Mauer muss weg! No metamuseu organizado pelo zelador da igreja, fotos, documentos e posters relatavam a passagem do tempo do muro. Mostrava ser os becos próximo a esta citada igreja, um dos lugares do despontar do movimento sponti, em que universitários, jovens, desocupados, hippies ocupavam casas vazias desvalorizadas pela presença do muro. Alguns destes territórios ocupados ainda permanecem. Alguns dos participantes do movimento na época ainda vivem nos entornos da praça em trailers. Tentamos nos aproximar para interagir, mas são adversos a visitas e proibiram fotografar.

O zelador do mini museu conta que na época os muros começaram a ser pintados, com frases de protesto. O próprio templo havia sido palco de reuniões de resistência. As marcas no muro cresciam em diversas zonas e registravam a sistemática crítica e oposição `a presença do muro da vergonha. As críticas, dizem os documentos, não eram só a presença do muro, eram também ao olhar do turista que vinha para admirar, de forma alienada, o muro. Fica evidente que as frases eram os gritos, os desenhos, os protestos, as pichações eram as reivindicações, táticas da resistência a la De Certeau (1994).

A busca da East Side Gallery era objetivo preeminente no dia. Lá voltaríamos várias vezes. Mas a primeira vez a gente nunca esquece. Não distante da Ostbahnhof, 
final de linha do nosso ônibus diário, em verdade a East Side Gallery fica do outro lado do rio Spree. Se não fosse o rio, era só caminhar duas quadras e lá estaríamos. Era preciso contornar e atravessar a ponte no Schillingbrucke, ou ao sul, a ponte Oberbaumbrucke (a linda ponte com estilo medieval).

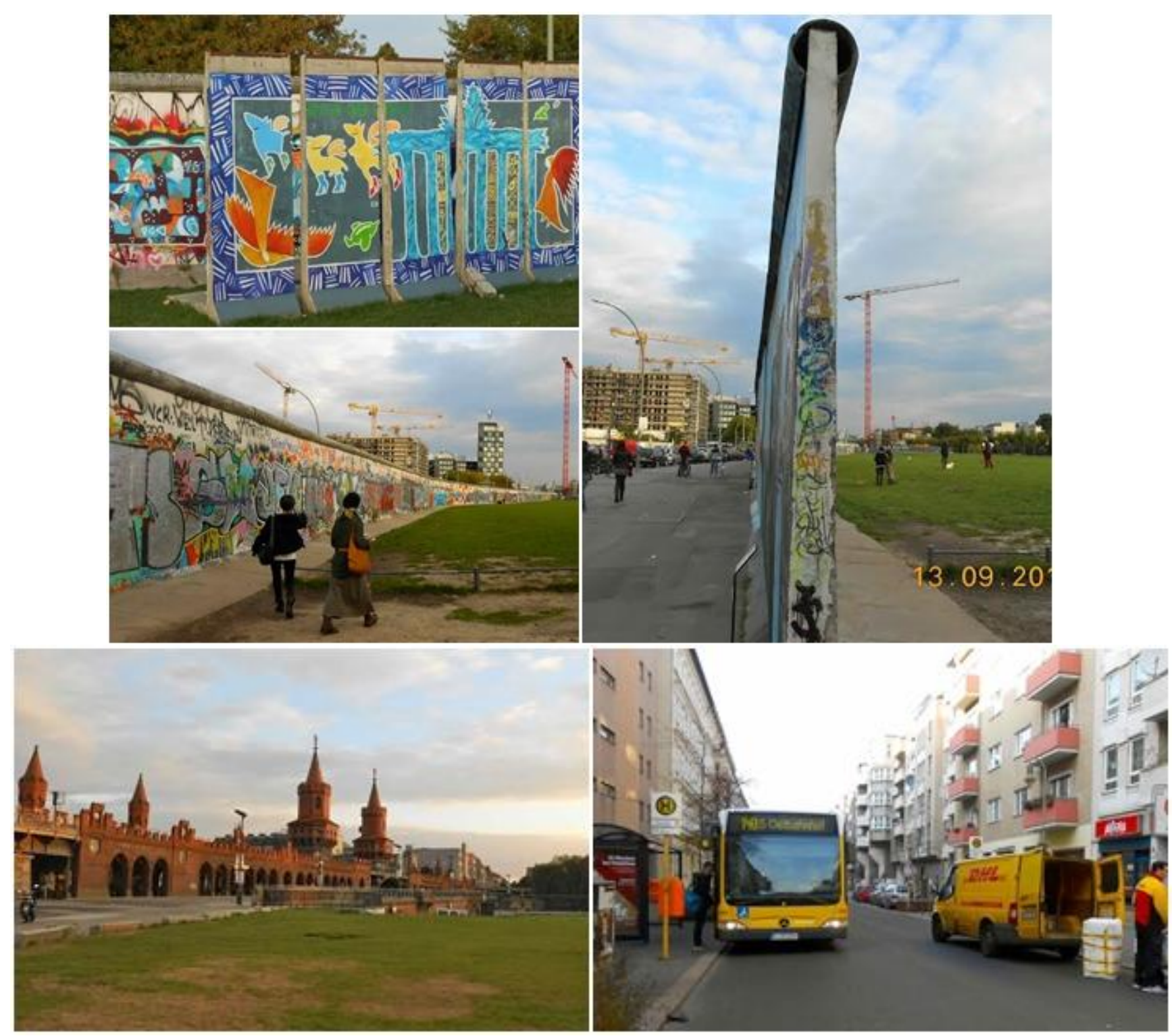

Berlim, 13 de setembro 2013. Fotos de Cornelia Eckert 

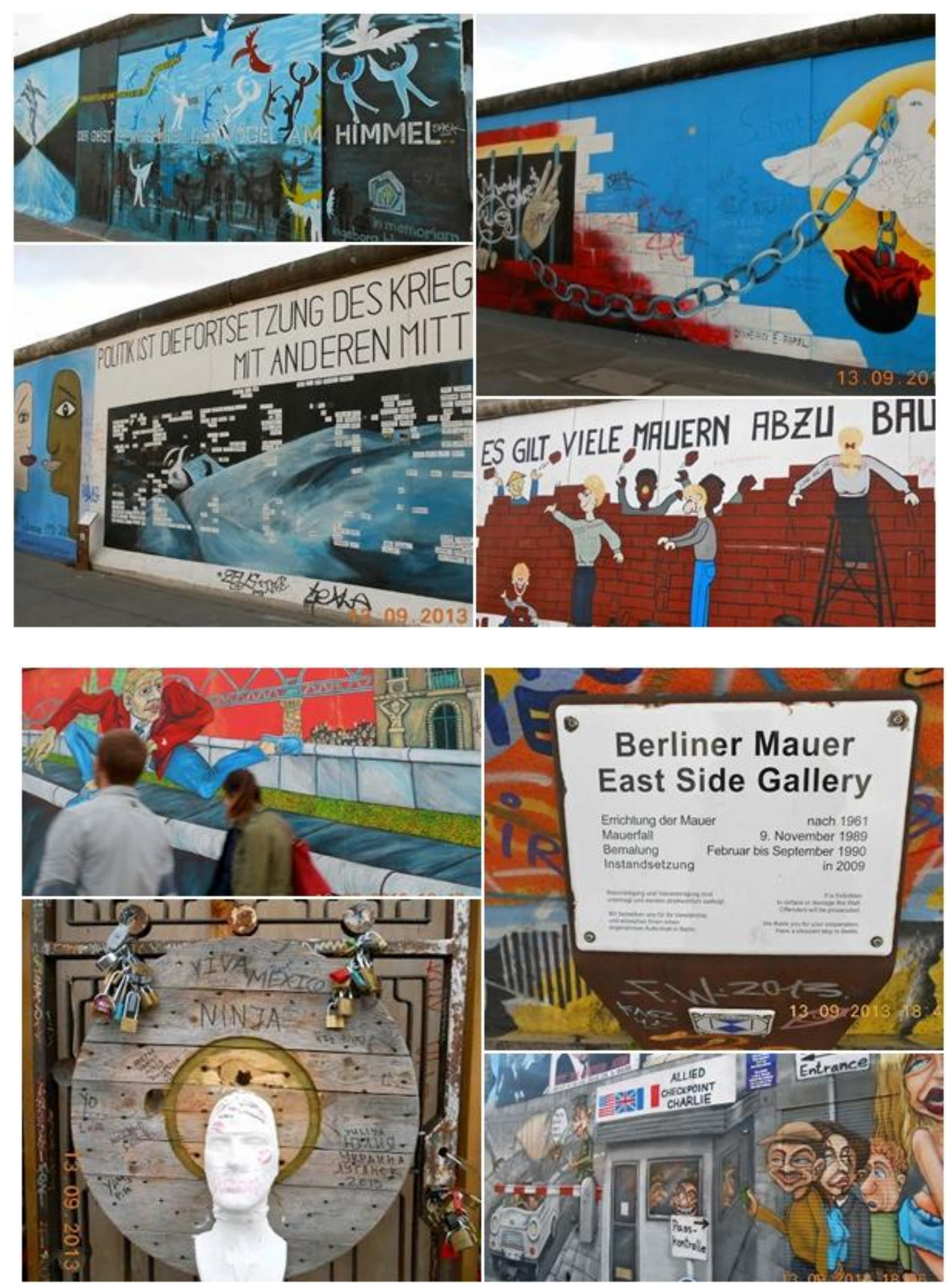

Berlim, 13 de setembro 2013. Fotos de Cornelia Eckert 
A galeria era muito longa, mas estávamos, apesar do calor, dispostas a enfrentar os muitos quilômetros a pé. Os grafittis eram muito sugestivos do clima de uma época, de protestos, de luta por um processo de reabertura da cidade cindida com a queda do muro. O histórico do monumento, dos artistas de 21 diferentes países que em 1990 passaram a intervir no muro, é conhecido e divulgado em vários portais e blogs eletrônicos. Fotografamos sistematicamente, não só nós, dezenas de turistas. Lá estavam repintados, entre outros, o beijo entre Leonid Brezhnev e Erich Honecker (ocorrido em 1979, evento comemorativo dos 30 anos da GDR) do russo Dimitrij Vrubel (Mein Gott hilf mir, diese todliche Liebe zu uberleben), o carro chamado trabant e fabricado na Alemanha Oriental cortando o muro, Test the Rest de Brigit Kinder, etc. A pintura de muro que nasce por volta de 1975, se tornou arte-cidade. Na palestra que escuto no Museu do bairro, o historiador Norbert Martins retoma os murais pintados e compara-os com o tom revolucionário do mural de Diego Rivera no Palácio Nacional do México.

\section{$O$ campo de refugiados}

Mais um dia para ir ao Museu do bairro, passar a tarde lá, ouvindo os depoimentos e tentar fazer contato para futuras entrevistas. Pretendo ficar, também, a noite para a conferência sobre a construção social da identidade cultural do bairro. Atravesso a rua e em frente da nossa casa observo uma Stolpersteine, uma pedra com o nome da família judia que ali havia residido antes de ser banida e a data da deportação para algum campo de concentração ou algum dos 40 mil lugares usados para torturar judeus na época nazista. Tiro foto. Já sei que é um dos projetos caro às pesquisas desenvolvidas pelo museu. 

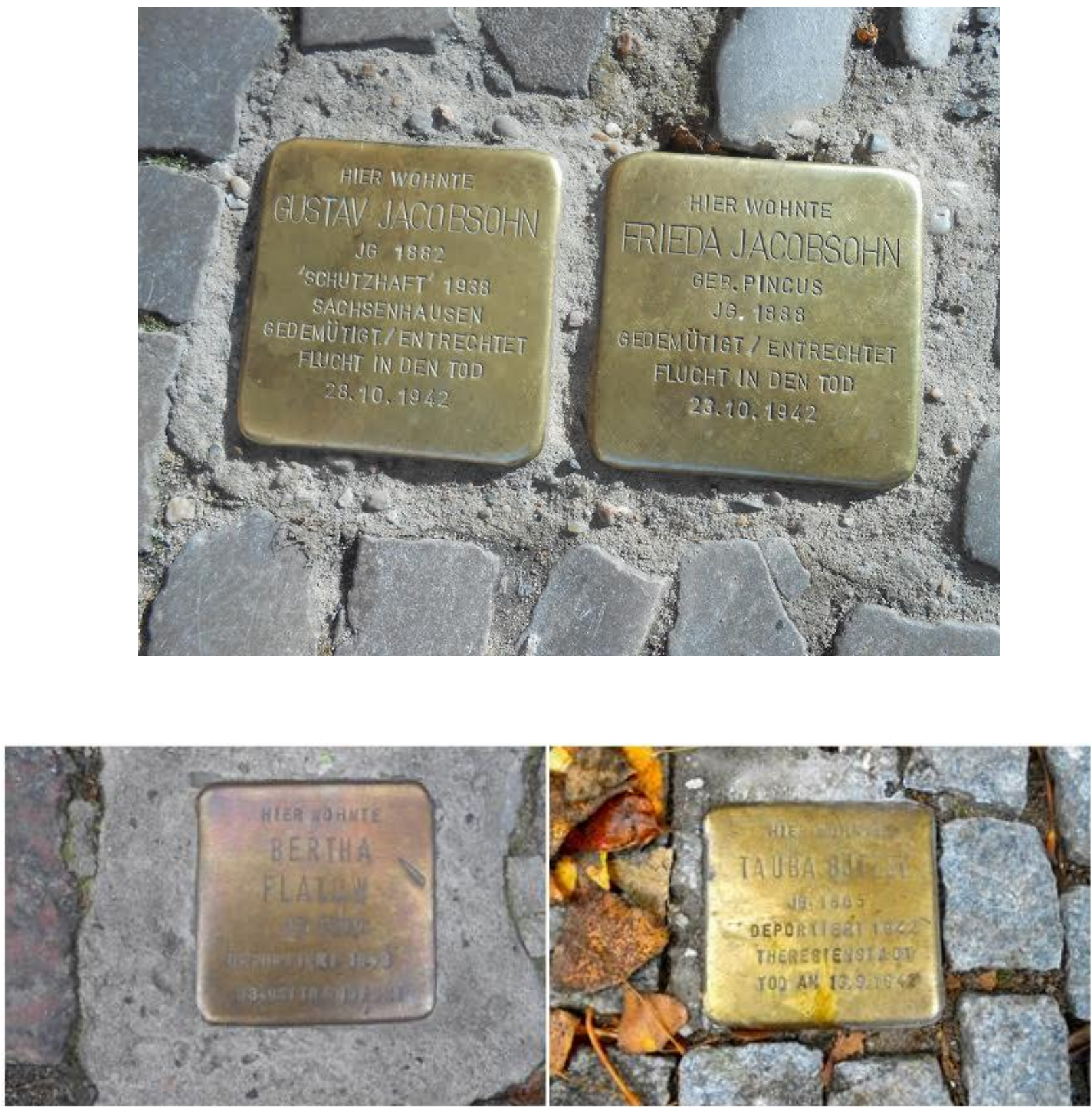

Berlim, setembro a novembro 2013. Fotos de Cornelia Eckert

A deportação dos judeus para Shoá, HaShoá, holocausto, holocaust: não importa a língua pronunciada, sempre será o horror, o absurdo, a catástrofe. A pedra pode ainda hoje ser solicitada para o projeto contra o esquecimento dos abusos "lembrar para o futuro". 

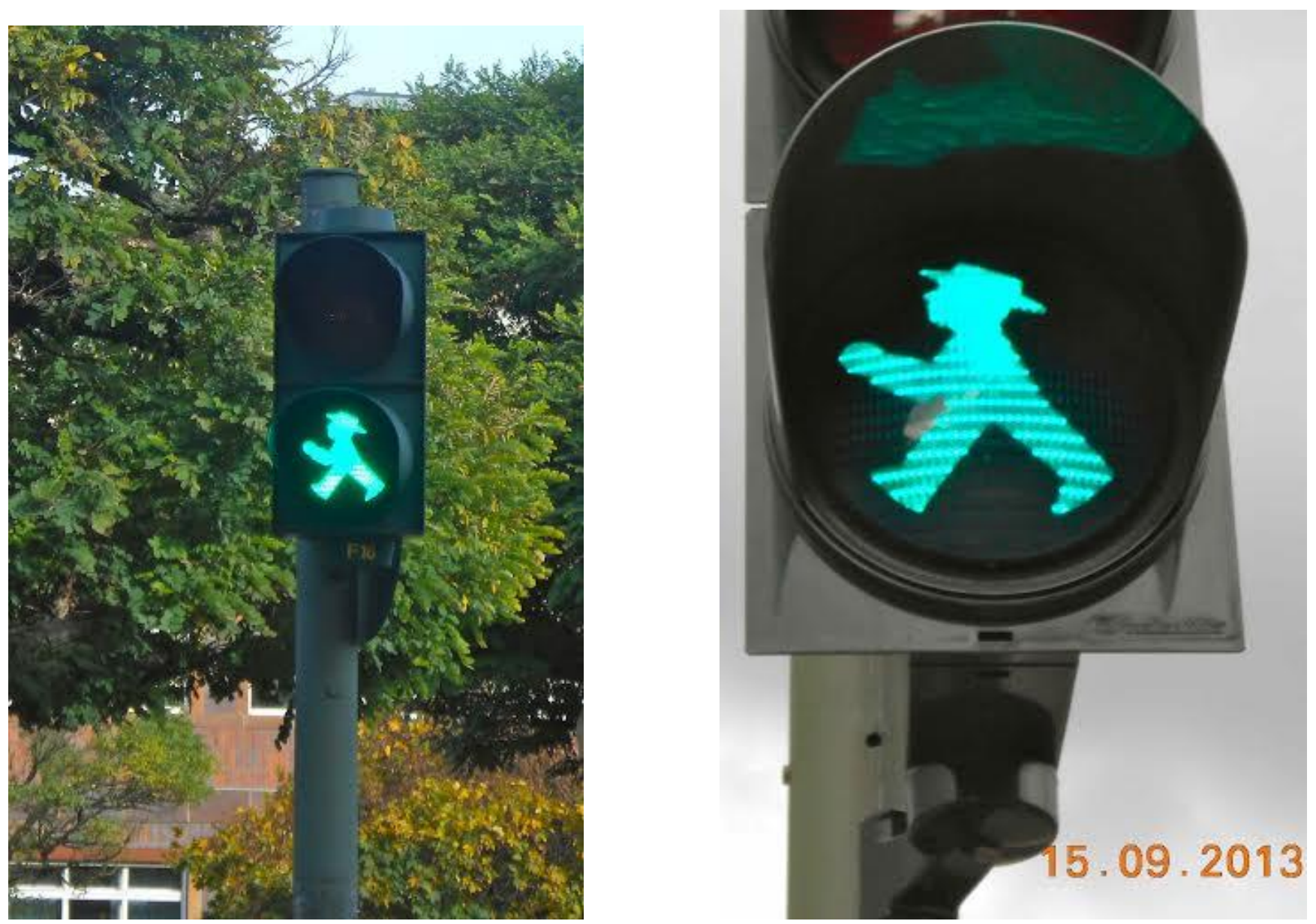

Berlim, novembro 2013. Fotos de Cornelia Eckert

Caminho pela Orianenstrasse. A sequencia de portas pichadas, de lojas e brechós com temáticas diversas, rock, jazz, Lampenmann (o boneco dos semáforos criado por Karl Peglau em Berlim Oriental em 1961), qualquer bar étnico mas principalmente mexicano, chinês, tailandês, turco, mais um turco, italiano. Fotografo os cartazes sobrepostos, híbrido de arte urbana, acúmulo de lixo ou simplesmente liberdade de expressão e divulgação.

Um desvio antes de chegar no museu. Passamos com frequência na praça no campo de refugiados. Caminho entre as barracas e espio a barraca principal. Não tenho 
coragem de fotografar. Leio os cartazes e resolvo fotografar outro dia, talvez com certa distância como a partir do ônibus, com parada em frente a principal barraco do campo.

Mas "voltando o disco", eu escrevi campo de refugiados? Como assim? Do que se trata? Estou etnografando um campo de refugiados?

Christel é nosso oitavo entrevistado formal, daquelas entrevistas combinadas para filmar "em algum lugar com certo silêncio" para a conversação fluir e depois em deslocamentos nas ruas, se possível. Ele foi indicado por Hélio, nosso terceiro entrevistado brasileiro. O berlinense-beninense é um militante e idealizador de uma Ong chamada Arts Vagabonds. Na primeira entrevista gravada em nossa casa, Christel conta que milita na luta pelos direitos dos refugiados propondo com eles atividades culturais. Escreveu uma peça de teatro para desenvolver com eles o que foi feito no ano passado. Fez uma longa oficina qualificando os refugiados voluntários como atores para contarem suas histórias. No verão de 2012, a peça fora apresentada em diversas ocasiões.

No dia 28 de outubro 2013 (segunda-feira) assisto no LAI a palestra da indiana Vibha Maurya sobre colonialismos comparados. Estava presentes o Prof. Sergio Buarque de Holanda do Brasil e Luciana Souto. A palestrante é especialista em Cervantes e traduziu Dom Quixote para o idich. Fico pensando no conceito de pós colonialismo. Após a palestra Ana e eu pegamos o taxi para ir até a prefeitura Steglitz, no sul de Berlim. Enquanto esperávamos observava um casal ele preto e ela branca se beijando exageradamente na esquina. $\mathrm{O}$ amor multicultural se expressando? Chega Christel e nos cumprimentamos em alemão mas logo passamos a nos comunicar em francês. Fomos conhecer o Programa Phoenix e a exposição dos jovens beninenses, projeto levado a termo por Christel. As telas foram feitas por beninenses a partir de uma pergunta, como você imagina que é viver na Europa? Percorremos os quadros com a câmera entrevistando Christel sobre a ação. Depois conversamos com a diretora sobre a proposta da casa cultural.

No retorno Christel pergunta se queremos ir com ele no campo de refugiados e aceitamos o convite dizendo que era um desejo nosso, mas que nos sentíamos inibidas de entrar em um ambiente tão masculino. Christel explica que as mulheres e as crianças estão "depositadas" em campos fora da cidade, onde estão acomodadas. A luta deles é pelo reconhecimento da legalidade dos refugiados em seus pedidos de asilo político 
com direito aos documentos para trabalhar com carteira assinada. Christel cumprimenta vários refugiados. Encontramos um amigo seu, um argelino que participara da peça de teatro. Uma conversa longa se inicia. Ele estava visivelmente bêbado ou drogado mas a conversa se manteve com sua narrativa sobre questões com a política, problemas de documentos e de saúde.

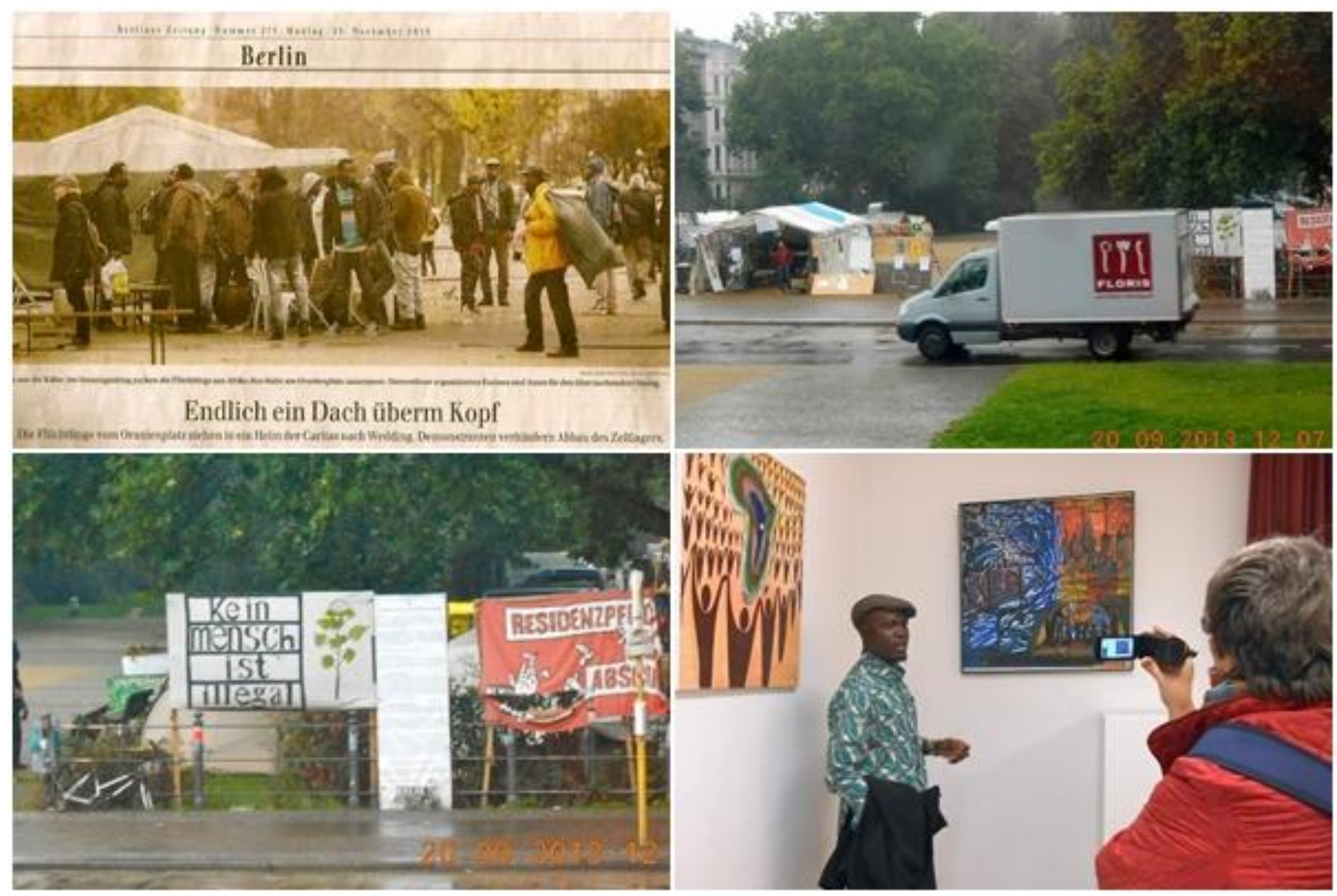

Berlim outubro 2013. Foto de Cornelia Eckert e artigo de jornal.

Tento comprar jornais que acompanham a situação dos refugiados. A prefeitura de Kreuzberg busca uma solução, diz o jornal Berliner Zeitung. Em novembro, com a aproximação do inverno, o Cáritas propõe um parque mais protegido no bairro Wedding para permanecerem até março de 2014. Mas o bairro principal de resistência na Orianenplatz permaneceria de plantão organizando manifestações sempre que necessário. Era 25 de novembro de 2013. 


\section{Sempre a dicotomia, adequado ou não? Ou o velho e bom para pensar}

Penso na adequação deste relato para apresentar no GT da 29 Reunião Brasileira de Antropologia, ocorrido em Natal (na UFRN) em agosto de 2014, intitulado As incertezas do trabalho de campo: narrativas sobre a pesquisa etnográfica, coordenado pelo poeta da palavra e mestre etnográfico, Hélio R. Silva e pela colega Ana Luiza. O paper é selecionado e me sinto autorizada. Também para este número da Revista Iluminuras, trago este relato, para trilhar nas narrativas inspiradas nos jogos das memórias puras da obra de Bergson e memórias involuntárias da obra de Marcel Proust refletidas por Walter Benjamin no ensaio "Sobre alguns temas em Baudelaire" (Benjamin, 1989: 103-150). Como relatar estes tempos vividos e pensados, sem recorrer a uma estilística narrativa?

Lembro também de outra inspiração. A do Anexo A. Aquele intitulado Sobre a evolução de Sociedade de Esquina de William Foote Whyte, escrita 40 anos após a publicação da obra de mesmo título, quando ele expõe seu diálogo com o personagem Chick sobre a coerência do livro do etnógrafo. Chick pergunta ao etnógrafo, "publicar este teu livro, faz algum bem"? Chick critica o livro quando consultado pelo autor Bill. Diz não concordar com alguns momentos de como ele havia sido apresentado pela autoridade do autor. "Você me apresenta", diz Chris, "como se eu pertencesse a um mundo bastante incivilizado". Segue reivindicando ao autor que ele devia esclarecer aos leitores que aquela etnografia relatava um momento de descontração. "Ao ler o livro", ficara decepcionado diz o informante principal do antropólogo, "tinha muita coisa em que ele não era mais o mesmo", de forma que o relato etnográfico deveria conter o clima, a ambiência, evidenciar a informalidade da relação, contextualizar a época, evidenciar a experiência geracional, pois como declara Chris "Mudei um bocado desde aquele tempo" (Foote-Whyte, 2005: 283-363).

Desta forma, nossos relatos servem para que exatamente? Ou para quem? É do desejo do(a) etnógrafo(a) que de alguma forma, seu relato embrenhe-se no círculo hermenêutico e ressoe "conhecimentos" sobre o relatado para a comunidade de comunicação. O grau de circularidade (leia-se internacionalidade) dependerá da qualidade do periódico, declara a comunidade científica, ou, depende do interesse (e da 
língua de leitura) dos interlocutores, almeja a comunidade antropológica. Embaraços e dilacerações da prática etnográfica deste ofício, reconhecido pela mediação do pesquisador entre muitos mundos, sempre in between. Deste exercício de deslocamentos, muitas narrativas, muitas estilísticas, almejando a partilha com a inteligibilidade narrativa dos leitores, e jamais restrita a cognoscência totalizante da burocracia científica.

Talvez vocês me digam, temos que primeiro diferenciar as boas etnografias das ralas, ligeiras, apressadas e um tanto informais como esta. Certo, não foi possível atingir as camadas profundas de reflexão e de exposições subjetivas em uma epistemologia crítica. Tampouco quisemos naturalizar um realismo social. Qual a estilística autorizada para traduzir as incertezas no trabalho de campo? Apostar na polifonia pode ser exagero de um gênero narrativo. E apostar na poética da cidade não é para todos os mortais. Resta-nos o exercício narrativo, sempre um aprendizado nas artes de fazer e dizer na vida ordinária do etnógrafo em meio as múltiplas redes de interlocução nas reinvenções do cotidiano almejadas por Michel De Certeau (1994). No final de contas, as narrativas ajudam a vibrar o tempo pensado e vivido. Talvez o fato de que os relatos etnográficos contrastem com a análise teórica obscura e generalizante criticada por Claude LéviStrauss (1962), seja um projeto consolidado da disciplina e nos incentive a continuidade destes exercícios de etnografia de (nas) rua(s), nos bairros, nas cidades.

Em Kreuzberg, em Berlim, vibra o tempo descontínuo dos instantes. Lá (escrevo aqui), podemos testemunhar as transformações de toda ordem que ressoam novos tempos. Esperamos que estes reverberem as estruturas performatizadas por Claude Lévi-Strauss (1962) "boas para pensar”, boas para viver, boas para durar, a humanidade em seu trajeto antropológico. 


\section{Referências}

ARANTES, Antônio A. Paisagens paulistanas, transformações do espaço público. Campinas, Ed. Unicamp. 2000.

BACHELARD, Gaston. A poética do espaço. São Paulo, Martins Fontes, 1993.

BACHELARD, Gastón. L'intuition de l'instant. Paris, Editions Gonthier, 1932.

BACHELARD, Gastón. La dialectique de la durée. Paris, Quadrige/PUF (1 ed. 1950) 1989.

BENJAMIN, Walter. Magia e Técnica, arte e Política: ensaios sobre literatura e história da cultura. São Paulo, Brasiliense, 1999.

BENJAMIN, Walter. Charles Baudelaire: um lírico no auge do capitalismo. In: Obras escolhidas III. São Paulo, Brasiliense, 1989. p. 9 a 181.

BERLINER ZEITUNG. Nummer 275, Montag 25 November 2013. p. 16. Artigo de Von Stefan Strauss. Fotografia de Berliner Zeitung Paulus Ponizak.

BOSI, Eclea. Memória e sociedade. Lembranças de velhos. São Paulo, Edusp, 1987.

CARDOSO DE OLIVEIRA, Roberto. Antropologia e Moralidade. http://www.anpocs.org.br/portal/publicacoes/rbcs 00 24/rbcs24 07. htm, consulta 02 junho 2014

DE CERTEAU, Michel. A invenção do cotidiano. Petrópolis, Vozes, 1994.

DOBLER, Jens. Von anderern Ufern. Berlin, Verlag, 2003.

DUFRENNE, Mikel. Phénoménologie de l'expérience esthétique. Paris, Klincksieck, 1967.

DUFRENNE, Mikel. Prefácio. Poétique de la ville. Paris, Payot, 2004. P. 7 a 14.

DUSPOHL, Martin (Dir.) et alli. Burbisse im Bocklerpark. Berlin, Kreuzberg Museum, 1994.

DÜSPOHL, Martin (Dir.) et alli. Made in Kreuzberg. Produkte aus Handwerk und Industrie. Berlin, Verlags, 1996.

DÜSPOHL, Martin (Dir) und KreuzbergMuseum (Hg.). Kleine Kreuzberg Geschichte. Berlin, Verlag, 2012.

ECKERT, Cornelia e ROCHA, Ana Luiza Carvalho da. A dialética da duração. Porto Alegre, Marcavisual, 2013. 
ECKERT, Cornelia e ROCHA, Ana Luiza Carvalho da. O tempo e a cidade. Porto Alegre: Editora UFRGS, 2005.

FLEMMING, Thomas (Documentation Berliner Mauer-Archiv. Hagen Koch). Le mur de Berlin. Une frontiere coupe la ville en deux. Berlin, Verlag, 2012.

FOOTE Whyte, William. Sociedade de esquina. Rio de Janeiro, Jorge Zahar, 2005.

FRAZER, Derek. Berlin, the buildings of Europe. New York: Manchester University Press, 1996.

FRISCHMUTH, Peter. Berlin Kreuzberg SO 36. Berlin, Verlag, 2012.

GIARD, Luce. Apresentação. A invenção do cotidiano. Petrópolis, Vozes, 1994. p. 9 a 34.

HARVEY, David. Condição pós-moderna. São Paulo, Loyola, 1993.

KOCH, Alexandre (Präs.) et alli. Zertörte Vielfalt. Berlin 1933-1938. Deutsches Historisches Museum. 31 Januar bis 10 november 2013. Berlin, DHM, 2013.

JABOBS, Jane. The Death and Life of Great American Cities. New York: Random House, 1961.

LEVI-STRAUSS, Claude. La pensée sauvages. Paris, Plon, 1962.

MARTINS, Norberto. Hauswande statt Leinwande. Berliner Wandbilder. Berlin, Hardcover, 2013.

MATURANA R., Humberto; VARELA GARCIA, Francisco J; ACUÑA LLORENS, Juan. De maquinas e seres vivos: autopoiese: a organização do vivo. 3.ed. Porto Alegre: Artes Medicas, 1997.

MUSEU KREUZBERG. Consulta a http://www.kreuzbergmuseum.de/index.php?id=295 nos meses de setembro e outubro 2013.

NUNGESSER, Michael. Orchidee der Brangelstrasse. Berlin, Kreuzberg Museum, 1999.

PADIGLIONE, Vincenzo. Efeito Marco - As Mediações do Patrimônio e a Competência Antropológica. Università degli Studi di Roma La Sapienza. E-mail: vincenzo.padiglione@gmail.com. Tradução: Dagoberto Bordin, Jeana Santos e Rafael O. Rodrigues. Universidade Federal de Santa Catarina, Florianópolis, Brasil. Consulta 23 e 24 setembro 2013. 
PEIRANO, Mariza. A teoria vivida e outros ensaios de antropologia. Rio de Janeiro, Jorge Zahar, 2006.

ROHNER, Ellen e STEFFEN, Erik (Hg.). Stillstand und bewegung. Menschen in Kreuzberg. Fotografien aus den 70 ern und 80 ern. Berlin, Verlag, 2913.

ROLDAO, Rafael. http://oglobo.globo.com/boa-viagem/em-berlim-kreuzbergdesponta-como-bairro-da-moda-2762340. Consulta setembro 2013.

SANTOT, Pierre. Poétique de la ville. Paris, Payot, 2004.

TEBBE, Krista et alli. Kreuzberg. Berlin, Kunstam Kreuzberg, 2000.

VIERGUTZ, Volker (seleção e notas). Die Berliner Mauer. Berlin, Ed. Berlin Story, 2013.

WEBER, Max. The city. NY, Free Press paperback edition, 1986 (1921 1. Ed).

Recebido em: 25/09/2014

Aprovado em: 10/11/2014 